\title{
The Perinatal Microbiome and Pregnancy: Moving Beyond the Vaginal Microbiome
}

\author{
Amanda L. Prince ${ }^{1}$, Derrick M. Chu ${ }^{1,2,3}$, Maxim D. Seferovic ${ }^{1}$, Kathleen M. Antony ${ }^{1}$, \\ Jun $\mathrm{Ma}^{1,4}$, and Kjersti M. Aagaard ${ }^{1,2,4,5}$ \\ ${ }^{1}$ Department of Obstetrics \& Gynecology, Division of Maternal-Fetal Medicine, Baylor College of Medicine, \\ Houston, Texas 77030 \\ ${ }^{2}$ Interdepartmental Program in Translational Biology and Molecular Medicine, Baylor College of Medicine, \\ Houston, Texas 77030 \\ ${ }^{3}$ Medical Scientist Training Program, Baylor College of Medicine, Houston, Texas 77030 \\ ${ }^{4}$ Bioinformatics Research Lab, Department of Molecular \& Human Genetics, Baylor College of Medicine, \\ Houston, Texas 77030 \\ ${ }^{5}$ Department of Molecular \& Cell Biology, Baylor College of Medicine, Houston, Texas 77030 \\ Correspondence: aagaardt@bcm.edu
}

The human microbiome, the collective genome of the microbial community that is on and within us, has recently been mapped. The initial characterization of healthy subjects has provided investigators with a reference population for interrogating the microbiome in metabolic, intestinal, and reproductive health and disease states. Although it is known that bacteria can colonize the vagina, recent metagenomic studies have shown that the vaginal microbiome varies among reproductive age women. Similarly, the richness and diversity of intestinal microbiota also naturally fluctuate among gravidae in both human and nonhuman primates, as well as mice. Moreover, recent evidence suggests that microbiome niches in pregnancy are not limited to maternal body sites, as the placenta appears to harbor a low biomass microbiome that is presumptively established in early pregnancy and varies in association with a remote history of maternal antenatal infection as well as preterm birth. In this article, we will provide a brief overview on metagenomics science as a means to investigate the microbiome, observations pertaining to both variation and the presumptive potential role of a varied microbiome during pregnancy, and how future studies of the microbiome in pregnancy may lend to a better understanding of human biology, reproductive health, and parturition.

$\mathrm{C}$ ompleted in 2012, the Human Microbiome Project (HMP) characterized the microbiome composition of multiple body sites in healthy individuals of different ethnicities lo- cated in two separate cities (St. Louis, Missouri and Houston, Texas) in the United States. This multicenter effort showed that bacterial diversity, niche specificity, and microbial gene car-

Editors: Diana W. Bianchi and Errol R. Norwitz

Additional Perspectives on Molecular Approaches to Reproductive and Newborn Medicine available

at www.perspectivesinmedicine.org

Copyright (C) 2015 Cold Spring Harbor Laboratory Press; all rights reserved; doi: 10.1101/cshperspect.a023051

Cite this article as Cold Spring Harb Perspect Med 2015;5:a023051 
A.L. Prince et al.

riage patterns far exceeded what was initially suspected (Aagaard et al. 2012a,b; Human Microbiome Project 2012a,b,c; Huse et al. 2012; Gevers et al. 2012; Li et al. 2012). These initial studies on the "healthy" reference human microbiome laid the foundation for a burgeoning wealth of investigations of the potential role of the microbiome in a spectrum of health and disease states. Indeed, associations between dysbiotic microbiota, or a microbial imbalance, and disease have been suggested for obesity, type II diabetes mellitus, ulcerative colitis, Crohn's disease, and colorectal cancer (Mangin et al. 2004; Ley et al. 2005; Gophna et al. 2006; Manichanh et al. 2006; Turnbaugh et al. 2006, 2008, 2009; Bäckhed et al. 2007; Cani et al. 2007; Willing et al. 2009; Larsen et al. 2010; Schwiertz et al. 2010; Wu et al. 2010; Joossens et al. 2011; Lepage et al. 2011; Marchesi et al. 2011; Sobhani et al. 2011; Qin et al. 2012; Wang et al. 2012; Devaraj et al. 2013). However, causation has yet to be established, and a multitude of other etiologies for these common, complex disorders have been suggested over the decades. Thus, it is critically important to first discriminate when in the course of the lifespan there is normal and anticipated variation in the human microbiome, in which body niches such variation occurs, and what other covariates (such as host diseasesusceptible genotype, host metabolic milieu and associated disorders, as well as age, gender, race/ ethnicity, and medications and diet) may contribute to any observed variation.

Our laboratory and others have shown that the vaginal microbiota vary in association with normal pregnancy, thus providing a unique "signature" in pregnancy with relative altered abundance of multiple taxa (Aagaard et al. 2012b; Romero et al. 2014b). This is intriguing, as the vaginal microflora influences gestational and postnatal health. It has long been suggested that intrauterine infections, such as chorioamnionitis, are the sequelae of ascending microbiota from the upper vaginal tract (Gonçalves et al. 2002), and the development of highly morbid neonatal conditions, such as neonatal sepsis and necrotizing enterocolitis, are potentially attributable to anatomical displacement of these flora with subsequent inflammation and neona- tal acquisition (Claud and Walker 2001; Guthrie et al. 2003; Yee et al. 2012). However, in this dawning era of metagenomic medicine and science, we are questioning these notions, and are coming to appreciate that many so-called "sterile" niches - notably in and among the female reproductive tract (such as the placenta) - may function as active low biomass ecologic niches that harbor unique microbiomes. These early observations challenge not only our assumed notions of "from when and where" our earliest microbiomes are colonized (or seeded), but our concepts of inflammatory mediators, reproductive immunity, and whether microbes in such niches may constitute more friend than foe.

Here, we will review the literature on how the microbiome is studied and how metagenomic science tools have been used in characterizing microbial communities and their genomic repertoire (Table 1). We will thereafter discuss findings by our group and others pertaining to the microbial ecology of pregnancy, with a focus on the potential role of the microbiome in mediating parturition and notably preterm birth. Finally, we will close with a discussion on future implications and applications as metagenomic medicine emerges as a frontier for both understanding and managing the most common and complex disorders of our current time.

\section{METAGENOMIC SCIENCE: METHODS, APPLICATIONS, AND CHALLENGES IN THE FIELD}

Mapping the human microbiome in reproduction requires that we not only characterize which microbes are present and what each taxon contributes to the biology of the host, but what their genetic repertoire entails and encodes for (so-called "gene carriage patterns"). Numerous methods have been developed to address these questions over the years, and with the advent of Next Generation (Next-Gen) sequencing, investigators have been able to relatively efficiently describe the composition of a microbial community. Additionally, other multi'omic techniques (e.g., metabolomics and metatranscriptomics) have been developed to attribute potential functions and metabolic capacity. 
Table 1. Metagenomic studies pertaining to perinatal health

\begin{tabular}{|c|c|c|c|c|c|}
\hline Reference & Site & Technique(s) & $\begin{array}{c}\text { Primers } \\
\text { used }\end{array}$ & Study design & Findings \\
\hline \multicolumn{6}{|c|}{ Nongravid Vaginal Studies } \\
\hline $\begin{array}{l}\text { NIH HMP } \\
\text { Consortium } \\
2012\end{array}$ & $\begin{array}{l}\text { Skin, nares, oral, } \\
\text { vagina }\end{array}$ & $\begin{array}{l}\text { Next-Gen } \\
\text { sequencing }\end{array}$ & $\begin{array}{l}\text { V1V3 } \\
\text { V3V5 }\end{array}$ & Longitudinal & $\begin{array}{l}\text { Characterized healthy } \\
\text { reference population }\end{array}$ \\
\hline $\begin{array}{l}\text { Ravel et al. } \\
\quad 2010\end{array}$ & $\begin{array}{l}\text { Mid-vagina } \\
\quad \text { (self-collected })\end{array}$ & $\begin{array}{l}\text { Next-Gen } \\
\text { sequencing }\end{array}$ & V1V2 & $\begin{array}{l}\text { Cross- } \\
\text { sectional }\end{array}$ & $\begin{array}{l}\text { Characterized healthy, } \\
\text { nongravid vaginal } \\
\text { microbiome }\end{array}$ \\
\hline $\begin{array}{l}\text { Gajer et al. } \\
2012\end{array}$ & $\begin{array}{l}\text { Mid-vagina (self- } \\
\text { collected) }\end{array}$ & $\begin{array}{l}\text { Next-Gen } \\
\text { sequencing }\end{array}$ & $\mathrm{V} 1 \mathrm{~V} 2$ & Longitudinal & $\begin{array}{l}\text { Showed temporal } \\
\text { dynamics of the } \\
\text { vaginal microbiome }\end{array}$ \\
\hline $\begin{array}{l}\text { Macklaim et al. } \\
2013\end{array}$ & Vagina & Metatranscriptomics & & $\begin{array}{l}\text { Cross- } \\
\text { sectional }\end{array}$ & $\begin{array}{l}\text { Showed potential for } \\
\text { metatranscriptomics } \\
\text { on vaginal swabs }\end{array}$ \\
\hline \multicolumn{6}{|c|}{ Gravid Vaginal Studies } \\
\hline $\begin{array}{l}\text { Aagaard et al. } \\
\text { 2012b }\end{array}$ & $\begin{array}{l}\text { Vaginal introitus, } \\
\text { posterior } \\
\text { fornix, and } \\
\text { mid-vagina }\end{array}$ & $\begin{array}{l}\text { Next-Gen } \\
\text { sequencing }\end{array}$ & V3V5 & $\begin{array}{l}\text { Cross- } \\
\text { sectional }\end{array}$ & $\begin{array}{l}\text { Characterized healthy, } \\
\text { gravid vaginal } \\
\text { microbiome }\end{array}$ \\
\hline $\begin{array}{l}\text { Romero et al. } \\
2014 b\end{array}$ & Posterior fornix & $\begin{array}{l}\text { Next-Gen } \\
\text { sequencing }\end{array}$ & V1V2 & Longitudinal & $\begin{array}{l}\text { Characterized healthy, } \\
\text { gravid vaginal } \\
\text { microbiome } \\
\text { throughout pregnancy }\end{array}$ \\
\hline $\begin{array}{l}\text { Walther- } \\
\text { António } \\
\text { et al. } 2014\end{array}$ & $\begin{array}{l}\text { Posterior fornix, } \\
\text { cervix }\end{array}$ & $\begin{array}{l}\text { Next-Gen } \\
\text { sequencing }\end{array}$ & V3V5 & Longitudinal & $\begin{array}{l}\text { Characterized healthy, } \\
\text { gravid vaginal } \\
\text { microbiome } \\
\text { throughout pregnancy }\end{array}$ \\
\hline \multicolumn{6}{|c|}{ Beyond the Vagina: Intestinal Microbiome } \\
\hline $\begin{array}{l}\text { Koren et al. } \\
2012\end{array}$ & Stool & Sequencing & V1V2 & Longitudinal & $\begin{array}{l}\text { Characterized first and } \\
\text { third trimester stool }\end{array}$ \\
\hline \multicolumn{6}{|c|}{ Beyond the Vagina: The Placenta } \\
\hline $\begin{array}{l}\text { Aagaard et al. } \\
2014\end{array}$ & Placenta & $\begin{array}{l}\text { Next-Gen } \\
\text { sequencing }\end{array}$ & $\begin{array}{l}\text { V1V3 and } \\
\text { WGS }\end{array}$ & $\begin{array}{l}\text { Population- } \\
\text { based, cross- } \\
\text { sectional }\end{array}$ & $\begin{array}{l}\text { The placenta harbors a } \\
\text { unique microbiome } \\
\text { profile, most akin to } \\
\text { the oral microbiome } \\
\text { and varies by virtue of } \\
\text { preterm birth and a } \\
\text { remote history of } \\
\text { antenatal infection }\end{array}$ \\
\hline \multicolumn{6}{|c|}{ Beyond the Vagina: Neonatal Studies } \\
\hline $\begin{array}{l}\text { Schultz et al. } \\
2004\end{array}$ & Stool & Sequencing & $\begin{array}{l}\text { Strain- } \\
\text { specific }\end{array}$ & Longitudinal & $\begin{array}{l}\text { Vertical transmission } \\
\text { from mother to infant }\end{array}$ \\
\hline $\begin{array}{l}\text { Palmer et al. } \\
\qquad 2007\end{array}$ & Stool & $\begin{array}{l}\text { Sequencing, } \\
\text { Microarray, PCR }\end{array}$ & $\begin{array}{l}\text { Universal } \\
16 \mathrm{~S} \\
\text { rRNA }\end{array}$ & Longitudinal & $\begin{array}{l}\text { Characterized healthy } \\
\text { neonatal microbiome }\end{array}$ \\
\hline $\begin{array}{l}\text { Dominguez- } \\
\text { Bello et al. } \\
2010\end{array}$ & $\begin{array}{l}\text { Oral, vagina, } \\
\text { skin, rectal }\end{array}$ & $\begin{array}{l}\text { Next-Gen } \\
\text { sequencing }\end{array}$ & $\mathrm{V} 2$ & $\begin{array}{l}\text { Cross- } \\
\text { sectional }\end{array}$ & $\begin{array}{l}\text { Characterized neonatal } \\
\text { microbiome by mode } \\
\text { of delivery }\end{array}$ \\
\hline
\end{tabular}


A.L. Prince et al.

Table 1. Continued

\begin{tabular}{|c|c|c|c|c|c|}
\hline Reference & Site & Technique(s) & $\begin{array}{c}\text { Primers } \\
\text { used }\end{array}$ & Study design & Findings \\
\hline $\begin{array}{l}\text { Koenig et al. } \\
2011\end{array}$ & Stool & $\begin{array}{l}\text { Next-Gen } \\
\text { sequencing }\end{array}$ & V1V2 & Longitudinal & $\begin{array}{l}\text { Characterized the } \\
\text { intestinal microbiome } \\
\text { from birth to } 2.5 \mathrm{yr}\end{array}$ \\
\hline Jost et al. 2012 & Stool & Sequencing & $\begin{array}{l}\text { Sanger, } \\
\text { V5V6 }\end{array}$ & Longitudinal & $\begin{array}{l}\text { Characterized healthy } \\
\text { neonatal microbiome }\end{array}$ \\
\hline $\begin{array}{l}\text { Wang et al. } \\
2013\end{array}$ & $\begin{array}{l}\text { Cord blood, } \\
\text { amniotic fluid }\end{array}$ & $\begin{array}{l}\text { Bacterial culture and } \\
\text { sequencing }\end{array}$ & $\begin{array}{l}\text { Universal } \\
16 \mathrm{~s} \\
\text { rRNA }\end{array}$ & $\begin{array}{l}\text { Cross- } \\
\text { sectional }\end{array}$ & $\begin{array}{l}\text { Neonates with } \\
\text { necrotizing colitis had } \\
\text { predominantly one } \\
\text { bacteria dominating }\end{array}$ \\
\hline $\begin{array}{r}\text { Milisavljevic } \\
\text { et al. } 2013\end{array}$ & $\begin{array}{l}\text { Gastro- } \\
\text { esophageal }\end{array}$ & Sequencing & $\begin{array}{l}\text { Universal } \\
16 \mathrm{~S} \\
\text { rRNA }\end{array}$ & Longitudinal & $\begin{array}{l}\text { Characterized the } \\
\text { microbiome in VLBW } \\
\text { infants }\end{array}$ \\
\hline $\begin{array}{l}\text { Azad et al. } \\
\quad 2013\end{array}$ & Stool & $\begin{array}{l}\text { Next-Gen } \\
\text { sequencing }\end{array}$ & $\begin{array}{l}\text { V5, V6, } \\
\text { V7 }\end{array}$ & Longitudinal & $\begin{array}{l}\text { Characterized the } \\
\text { neonatal microbiome } \\
\text { from birth to } 4 \text { mo } \\
\text { while examining mode } \\
\text { of delivery and feeding }\end{array}$ \\
\hline $\begin{array}{l}\text { Rogier et al. } \\
2014\end{array}$ & Stool & Microarray & & Murine & $\begin{array}{l}\text { Examined the role of } \\
\text { maternal IgA on } \\
\text { intestinal microbiome }\end{array}$ \\
\hline Ma et al. 2014b & $\begin{array}{l}\text { Colon, anus, } \\
\text { stool }\end{array}$ & $\begin{array}{l}\text { Next-Gen } \\
\text { sequencing }\end{array}$ & V3V5 & $\begin{array}{c}\text { Nonhuman } \\
\text { primate }\end{array}$ & $\begin{array}{l}\text { Examined the role of } \\
\text { maternal diet on } \\
\text { juvenile microbiome }\end{array}$ \\
\hline
\end{tabular}

\section{S-Based Metagenomics}

Sequencing of the $16 \mathrm{~S}$ rRNA gene using NextGen technology has recently been widely exploited to characterize the human microbiome (Jonasson et al. 2007; Liu et al. 2007). The 16S rRNA gene is an ideal target to classify bacteria because of the nine hypervariable regions in this gene that can be used to distinguish species based on individual nucleotide polymorphisms (Fig. 1A). Ergo, Next-Gen sequencing characterizes both coarse ( phylum level) as well as fine (genus and limited species and strain) differences using universal primers to the adjacent conserved regions (Klindworth et al. 2013). However, 16S-amplicon-based approaches are limited to a shorter read length as compared with Sanger sequencing, and as a result, only a few hypervariable regions can be contiguously sequenced at a time. Initial work on approach and validation by the HMP Consortium showed that there is variation in the taxonomy profile identified based on sequencing different variable regions. For example, V1V3 amplicons may underestimate Acinetobacter and Escherichia genera, but V3V5 provides both breadth and depth of communities dominated by these genera. Furthermore, V6V9 may underestimate Bacteroides but provides good coverage for Pseudomonas and Escherichia (Human Microbiome Project 2012b).

Comparison of the vaginal microbiome data from the HMP reveals that V1V3 will distinguish communities primarily by the relative predominant Lactobacillus species present whereas, V3V5 amplicons will reveal either lactobacilli-dominant or lactobacilli-diminished groups. Furthermore, the number of Lactobacillus species detected (and thus relative abundance) will vary depending on the $16 \mathrm{~S}$ region sequenced, with V1V3 revealing more unique Lactobacillus operational taxonomic units (OTUs) as compared with V3V5 (Huse et al. 2012). However, unlike V3V5, V1V3 does not 


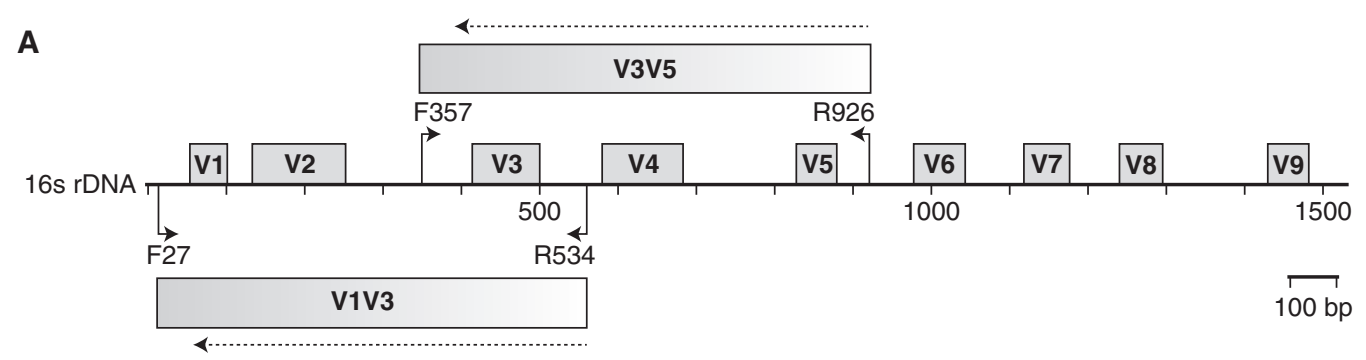

B

\begin{tabular}{rcc} 
& V1V3 & V3V5 \\
Lactobacillus & ++ & -- \\
Prevotella & + & - \\
Enterobacteriaceae & - & ++ \\
\hline Bifidobacteriaceae & - & ++ \\
Staphylococcus & - & + \\
Clostridium & + & +
\end{tabular}

Figure 1. The $16 \mathrm{~S}$ rDNA gene is an ideal target for classifying bacteria. (A) The $16 \mathrm{~S}$ rDNA gene of bacteria contains nine hypervariable regions $(\mathrm{V} 1-\mathrm{V} 9)$ that are flanked by conserved regions, which makes this gene an ideal target for PCR amplification and bacterial classification. The V1V3 and V3V5 primers sets used by the HMP consortium are outlined. The dotted line indicates the direction of amplification. $(B)$ Advantages and disadvantages to characterizing the vaginal microbiome with V1V3 (includes V2) and V3V5 (includes V4) primer sets. Species identification of Lactobacillus is enabled using a V1V3 primer set; however, V3V5 primers sets are better suited to identify Enterobacteriaceae and Bifidobacteriaceae. Thus, experimental design is essential when examining the pregnant microbiome.

fully discriminate Enterobacteriaceae family projections (including Escherichia and Proteus), and some genera (including Staphylococcus) (Fig. 1B) (Fettweis et al. 2012). Few studies have directly compared the vaginal communities described by V6, V7, V8, and V9 to other primer sets, although a number of studies have used these regions with good coverage (Hummelen et al. 2010; Ghartey et al. 2014). Taken together, these data emphasize the need for prudent consideration when choosing primer sets for sequencing with appreciation of both the body site to be characterized, the reference data set to be compared with, and limitations when comparing to other published findings.

Numerous bioinformatics suites, such as Quantitative Insights into Microbial Ecology (QIIME), Mothur, and Genboree, have been developed specifically to handle the taxonomic information gathered from $16 \mathrm{~S}$ studies (Schloss et al. 2009; Caporaso et al. 2010; Riehle et al. 2012). These tools streamline the process of qual- ity filtering, operation taxonomic unit (OTU) picking, chimeric sequence removal and taxonomic assignment. For rapid and accurate taxonomic assignment, several reference databases, including Ribosomal Database Project (RDP), SiLVA, and Greengenes, have curated full length $16 \mathrm{~S}$ sequences for more than 700 distinct taxa (DeSantis et al. 2006; Pruesse et al. 2007; Wang et al. 2007). Lastly, these bioinformatics tools can perform basic microbial community analysis, including measuring alpha diversity (within sample variation) and beta diversity (between sample variation).

\section{Whole Genome Shotgun (WGS)-Based Metagenomics}

Although $16 \mathrm{~S}$ sequencing is a cost effective approach to perform metagenomics studies, whole genome shotgun (WGS) sequencing allows for deep and refined taxonomic classification to the species and strain level, as well as the 
A.L. Prince et al.

capacity to capture total gene content and metabolic capacity (Butler et al. 2008; Liu et al. 2012; Morgan et al. 2012; Qin et al. 2012; Aagaard et al. 2014). However, the sheer volume of data generated by this approach poses significant bioinformatics challenges (Prakash and Taylor 2012). On receiving sequence reads, quality filtering is performed to remove human contamination, which consists of $>90 \%$ of reads in vaginal or placental samples (Human Microbiome Project 2012c; Aagaard et al. 2014). To get species assignment to provide potential gene expression information, sequence reads are first assembled into contigs, or genes. This is challenging because of the lack of reference genomes, which results in de novo assembly of microbial genomes with the potential to distort the species abundance and generate chimeric genomes (Pop 2009). Following assembly, gene prediction is then possible by analyzing molecular characteristics of existing open reading frames of sequenced genomes (Zhu et al. 2010). Given the complexity of assembly and low efficiency, taxonomy classification can also be achieved by alignment of sequence reads to clade-specific markers identified from integrated microbial genomes (IMG) without prior assembly (Segata et al. 2012). The reconstruction of functional profile is achieved by mapping reads onto pathway collections such as Kyoto Encyclopedia of Genes and Genomes (KEGG), with additional interference steps for pathway coverage and abundance (Abubucker et al. 2012). Further, web tools have recently been developed to perform the tasks described above to facilitate the analysis of WGS data (Glass et al. 2010). However, regardless of approach, WGS and 16 S sequencing are limited to describing community composition and its potential metabolic or functional capability.

\section{Multi'omics Data Integration}

To truly understand how the microbiome impacts human health, metabolomic and metatranscriptomic approaches will be required to characterize their precise roles as symbionts (reviewed in Morgan and Huttenhower 2014). Metatranscriptomics, unlike its DNA-based counterparts, reveals dynamic gene expression patterns and nonprotein-coding small RNAs present in microbial communities. Therefore, metatranscriptomics can elaborate more precisely how bacteria are contributing to host biology. However, the current challenge in this area of research is how to remove host nucleotides and rRNA while preserving the shorter microbial transcripts (Booijink et al. 2010; Gosalbes et al. 2011; Schmieder et al. 2012). Once this challenge is overcome, the analysis of metatranscriptomics could use previous statistical methods developed for RNA-seq studies.

Metabolomics will be similarly critical for linking bacterial function to host health. Although studying the collection of metabolites associated with a microbial community is not unlike studying single organisms, associating individual metabolites with the microbe of origin is a significant challenge. Because microbes provide metabolic capabilities otherwise unavailable to the host, observing alterations in metabolites through changes in diet or the use of antibiotics in correlation with the microbiome may help us decipher the interrelationships between bacteria and their corresponding metabolomics (Zhang et al. 2010; Sellitto et al. 2012; McHardy et al. 2013). Although it is currently challenging to fully integrate multi'omics data, meaningful associations are beginning to be established through correlations, network analysis, and co-occurrence analysis (Shi et al. 2011; Faust et al. 2012; McHardy et al. 2013; Morgan and Huttenhower 2014).

\section{THE VAGINAL MICROBIOME IN REPRODUCTIVE AGED WOMEN}

Before the advent of Next-Gen sequencing, the characterization of the vaginal microbiome through traditional microbiological techniques (culture-dependent) revealed a predominance of Lactobacillus species (Redondo-Lopez et al. 1990; Larsen and Monif 2001). These early characterizations of the vaginal microbiome resulted in the delineation of "normal" flora (defined as Lactobacillus predominant), and "abnormal" or "aberrant" vaginal flora (nonlactobacillus predominant). Early descriptions 
also attempted to characterize abnormal vaginal flora, most notably in conjunction with bacterial vaginosis (BV). BV is a common and complex alteration of vaginal flora, but the description of the bacteria involved in the vaginal dysbiosis has changed over time. The association between anerobic cocci and abnormal vaginal discharge was first described by Curtis in 1914, and Gardnerella vaginalis was first described as a causative agent for BV in 1955 (Eschenbach 1993; Ledger 1993). However, by the 1990s, multiple other species were found in anaerobic cultures of vaginal discharge from subjects with symptoms consistent with BV (Faro et al. 1993; Hillier et al. 1993). Despite the multiplicity of causative agents, one common finding is that women experiencing clinically symptomatic $\mathrm{BV}$ tend to be deficient in lactic acid producing species of bacteria that also convert oxygen to $\mathrm{H}_{2} \mathrm{O}_{2}$ (Eschenbach et al. 1989; Hillier et al. 1992, 1993). This observation has led to several decades of data demonstrating that adverse reproductive health outcomes accompany "abnormal flora" associated with BV (Gravett et al. 1986; Martius et al. 1988; Krohn et al. 1991; Hillier et al. 1995a; Martin et al. 1999; Wiesenfeld et al. 2003; Ness et al. 2005; Brotman et al. 2010). For instance, the incidence of BV has been associated with preterm birth and with increased risk for acquiring sexually transmitted diseases, such as Neisseria gonorrhea, Chlamydia trachomatis, and human immunodeficiency virus (HIV) (Gravett et al. 1986; Martius et al. 1988; Krohn et al. 1991; Kurki et al. 1992; Hillier et al. 1995b; Martin et al. 1999; Wiesenfeld et al. 2003; Ness et al. 2005; Brotman et al. 2010; Perla et al. 2012). This increased risk of infection is thought to be because of the deficiency of $L a c$ tobacillus species that produce lactic acid and $\mathrm{H}_{2} \mathrm{O}_{2}$ to provide protection from pathogenic bacteria and viruses (Eschenbach et al. 1989). Along these lines, previous in vitro studies have shown that Lactobacillus acidophilus can protect from infection with $G$. vaginalis, Bacteroides bivius, and HIV through a peroxidase dependent mechanism (Klebanoff and Coombs 1991; Klebanoff et al. 1991). Thus, although BV may indicate vaginal dysbiosis in a clinical setting, there has been historically a lack of data regarding whether vaginal dysbiosis occurred as "normal" flora in women asymptomatic for BV. Currently, Next-Gen sequencing techniques have enabled the vaginal microbiome to be more thoroughly characterized to determine the bacterial flora of the "normal" versus "abnormal" vagina.

One of the first studies to reveal the complexity of the vaginal microbiome using NextGen techniques was performed by Ravel et al. This study recruited nearly 400 women of mixed ethnicities. Samples were prepared for either V1V2 16S sequencing and were scored for BV using Nugent criteria (Ravel et al. 2010). Five distinct community state types (CSTs) were revealed, and the majority of these CSTs were dominated by species of lactobacilli. The fourth CST included women with a vaginal microbiome deficient in Lactobacillus species, and interestingly, this group had increased incidence of BV. Also, this study showed that the vaginal microbiome could be distinguished by ethnicity. Asian subjects had a higher prevalence of CST III (Lactobacillus iners), non-Hispanic Caucasians had a higher prevalence of CST I (Lactobacillus crispatus), and African-American and Hispanic subjects had a higher prevalence of CST III (L. iners) and IV (decreased Lactobacillus species) (Ravel et al. 2010). However, recent studies have shown the caution that must be used when performing analysis such as CSTs (Koren et al. 2013). In these investigations, Koren et al. (2013) showed that these types of cluster analysis are sensitive to the distance metric used for analysis and that multiple distance metrics should be used to promote accuracy in data. In fact, this study used the data of Ravel et al. (2010) in their analysis and found varying support for the presence of CSTs based on the analysis used (Koren et al. 2013). Thus, multiple methods of analysis must be used to establish a CST. An additional method that may be useful to examine microbiome communities across ethnicities is to use single nucleotide polymorphisms (SNPs) in mitochondrial DNA (mtDNA), which provides more precision in analysis (Ruiz-Pesini et al. 2007). We have recently used this method in conjunction with analysis of the microbiome through data leveraged from the HMP to examine associations 
A.L. Prince et al.

between mtDNA haplotypes and microbiome communities (Ma et al. 2014a). Although we did see similar microbiome communities as the Ravel group, our analysis has provided a molecular basis in which to describe the structure of microbiome communities ( $\mathrm{Ma}$ et al. 2014a).

Although this initial study revealed the complexity of the vaginal microbiome, it did not determine the stability of the vaginal microbiome. This aspect was queried in a separate study in which 32 subjects, mostly AfricanAmerican and non-Hispanic Caucasian, selfcollected vaginal samples over a 16 wk time frame (Gajer et al. 2012). Intriguingly, the stability of the vaginal microbiome over time appeared to vary by individual. In other words, some women tended to have high variability in their vaginal microbiome, even to the extent in which the CST classification of their vaginal microbiome was altered up to three times over the course of the study (Gajer et al. 2012). However, other women tended to have an incredibly stable vaginal microbiome throughout the study (Gajer et al. 2012). Because this study had a limited number of subjects and ethnic diversity, it is challenging to determine how host genetics may be associated with variability in the stability of the vaginal microbiome between subjects. Thus, utilizing the mtDNA haplogroups described above may be of great utility in future studies that examine the stability of any microbiome community over time. Additionally, fluctuations in alpha diversity were associated with the menstrual cycle, such as increased levels of estradiol and progesterone corresponded to decreased diversity (Gajer et al. 2012). Increases in these hormones promote the presence of lactic acid producing bacteria, which maintain low $\mathrm{pH}$ and low diversity in the vagina.

Alterations in the vaginal microflora attributed to $\mathrm{pH}$ have been described to have functional consequences as well. Using inferred function analysis obtained from WGS sequencing data, the HMP consortium noted that a decrease in the vaginal $\mathrm{pH}$ corresponded to an increase in metabolic activity, specifically when examining the phosphate transport system (Human Microbiome Project 2012c). Even further, a recent study examined the vaginal metatranscriptomics profile of two women with healthy vaginal profiles and two women diagnosed with BV. This group found that there were distinct differences in expression of CRISPR-related genes, butyrate production, and glycogen metabolism (Macklaim et al. 2013). In women with healthy vaginal microflora, glycogen metabolism resulted in the production of lactic acid although subjects with $\mathrm{BV}$ had an increase in succinate production (Macklaim et al. 2013). What is even more intriguing is that some of these differences appeared to be attributable to gene regulation by L. iners. Thus, this study exemplifies the need for further metatranscriptomic and metabolomic studies involving large cohorts to understand the role of the reproductive microbiome in health and disease.

\section{THE VAGINAL MICROBIOME IN PREGNANCY}

With the demonstration that the vaginal microbiome fluctuates based on the menstrual cycle, with intercourse, and (to a much more limited degree) with clinical symptoms of BV, we and others sought to characterize the vaginal microbiome during pregnancy. Nearly every organ system changes during pregnancy to promote pregnancy maintenance or prepare for parturition. In the vagina, increased vascularity and hyperemia develop in the skin of the vulva and the mucosa of the vagina. Additionally, the vaginal mucosa increases in thickness and cervical secretions increase, which causes the underlying smooth muscle cells to hypertrophy and relax the connective tissue. At the epithelial surface, the vaginal epithelium hypertrophies and causes a crowding of the epithelial cells, which are rich in glycogen (Nieburgs 1947). Estrogen (namely estradiol) rises across gestation, and further leads to increases in glycogen levels; glycogen is metabolized into lactic acid resulting in the decrease $\mathrm{pH}$ (acidity) of the vagina (Gregoire et al. 1971; Paavonen 1983). This metabolism of glycogen into lactic acid was historically thought to be performed by the vaginal epithelium, because the vaginal lumen is suffi- 
ciently distant from the oxygen supply to become anaerobic. However, the primary source of lactic acid became debated when Boskey et al. reported that vaginal lactobacilli were capable of producing lactic acid in vitro at a rate sufficient to reacidify the vagina in vivo following a neutralizing exposure (i.e., ejaculate) (Boskey et al. 1999; Pybus and Onderdonk 1999). Afterward, the specific lactate structures in the vagina were explored and it was discovered that the majority of the vaginal lactic acid was of the D-isoform, which cannot be produced by human metabolism (Boskey et al. 2001). Thus, vaginal bacteria, namely lactobacilli, appear to be the primary source of lactic acid in the vagina. In pregnancy, the preponderance of Lactobacillus species appears to be aided by the estrogen-induced increase in glycogen that contributes to the vaginal acidic environment, which is not only enhanced by lactobacilli but also fosters Lactobacillus growth.

Before the advent of metagenomics, the presence of lactobacilli were noted to increase as gestational age advanced during pregnancy (Nieburgs 1947). Further, more recent studies showed a high prevalence of Lactobacillus species in the vagina during either the first, second, or third trimester using PCR-denaturing gradient gel electrophoresis (DGGE) for the V3 region of the $16 \mathrm{~S}$ rRNA gene, and the species with the highest prevalence were $L$. acidophilus and L. iners (Hernández-Rodríguez et al. 2011). The utilization of Next-Gen sequencing techniques to study the vaginal microbiome further showed the presence of Lactobacillus species in the vagina during pregnancy. Our group initially published this $16 \mathrm{~S}$-based metagenomic characterization in a cross-sectional study (Aagaard et al. 2012b). We used V3V5 16S sequencing and examined the posterior fornix, mid-vagina, and vaginal introitus of 24 gravid and 60 nongravid subjects. Vaginal samples collected from a cross-sectional survey of gravid subjects from 18 wk gestation to term or delivery, and all samples were collected by a single physician who also conducted the HMP sampling for $50 \%$ of subjects. All samples were extracted in a manner identical to that used by the HMP, and sequenced on the same pipelines. When com- pared with the HMP nonpregnant reference subjects, we found that pregnancy was associated with an altered vaginal microbiome and marked by a decrease in alpha diversity at the subgenus level (Fig. 2) (Aagaard et al. 2012b). When we examined this phenomenon further, we discovered that there was an overall enrichment of the orders Lactobacillus, Clostridiales, Bacteriodales, and Actinomycetales. And on probing at the species level using supervised machine learning approaches, such as linear discriminate analysis (LDA) effect size (LEfSe) and Boruta feature selection, we discovered that the vaginal microbiome during pregnancy was enriched in L. iners, L. crispatus, Lactobacillus jensenii, and Lactobacillus johnsonii (Aagaard et al. 2012b). The increase in lactobacilli may be explained by the increase in estrogen that occurs during pregnancy. However, direct associations between specific species of Lactobacillus and estrogen levels are lacking and warrant further investigation.

However, the aforementioned studies were cross-sectional, which allows for the characterization of a pregnancy and gestational age-common microbiome signature, but lacks capacity for description of the dynamic changes, which may occur in an individual over time. Longitudinal analysis of the vaginal microbiome in a small cohort of women across gestation has been performed using terminal restriction fragment length polymorphism (tRFLP) in 100 gravid women (Verstraelen et al. 2009). This study categorized gravidae into two cohorts during the first trimester: lactobacilli-dominant and lactobacilli-diminished. Interestingly, only $16.9 \%$ of gravidae that had a lactobacilli-dominant vaginal microbiome in the first trimester decreased the prevalence of lactobacilli during pregnancy. On the other hand, 56.5\% of gravidae with a lactobacilli-diminished vaginal microbiome during the first trimester gained prevalence of this genus. In contrast to the cross-sectional study, these longitudinal cohorts showed that $L$. crispatus dominated during pregnancy and that prominence of Lactobacillus gasseri and/or L. iners during the first trimester may be associated with diminished lactobacilli as pregnancy progressed (Verstrae- 
A.L. Prince et al.

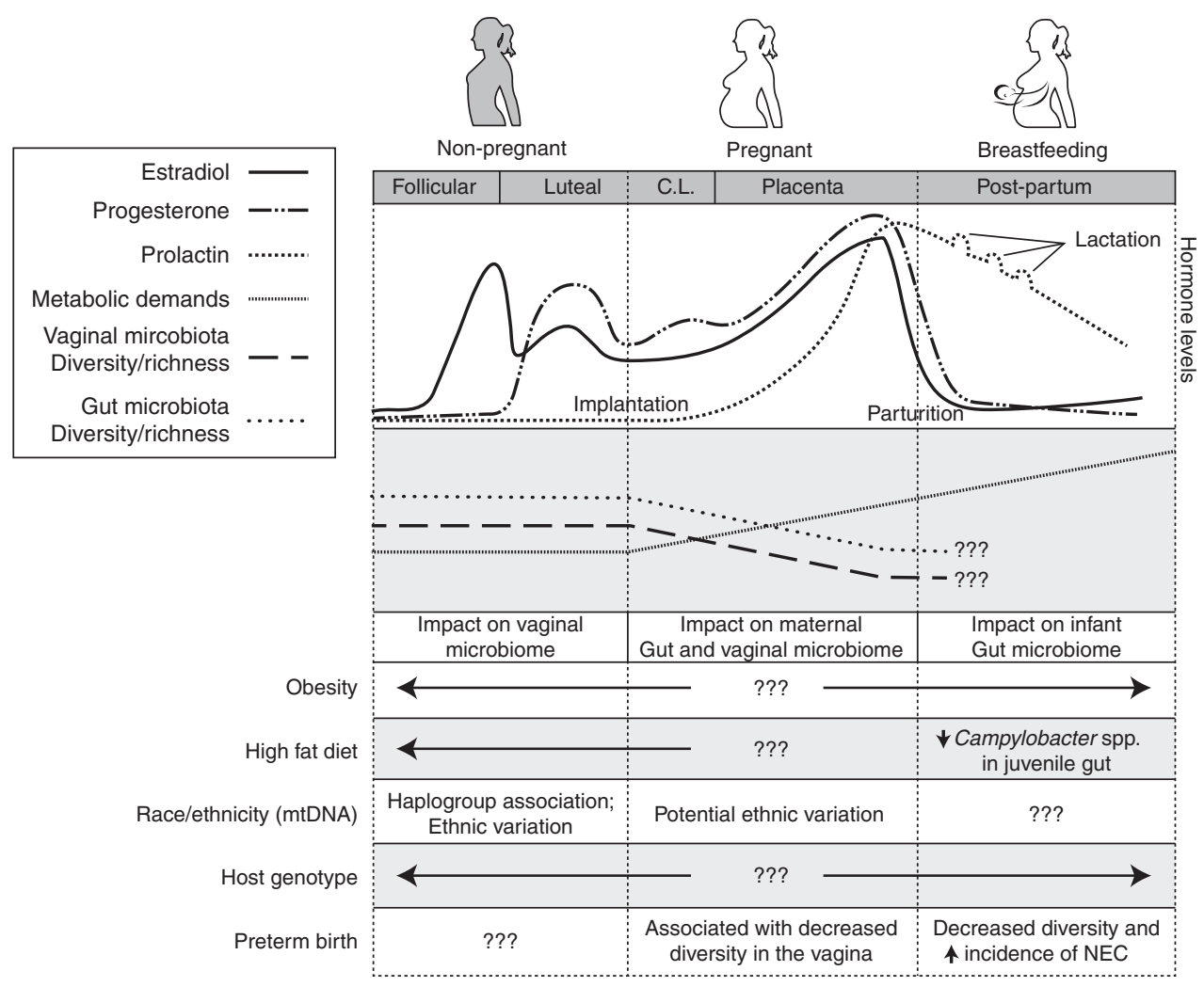

Figure 2. Influences on the pregnant microbiome. A number of hormonal changes, environmental exposures and genetic differences may impact the maternal microbiome before and during pregnancy that may alter the developing neonatal microbiome. During pregnancy, the maternal intestinal and vaginal microbiome have reduced alpha diversity and species richness. Metabolic demands increase throughout pregnancy and after parturition as the mother is lactating. Estradiol, progesterone and prolactin levels gradually increase during pregnancy, although it is unclear how these changes affect the maternal microbiome. Increased estrogen raises glycogen production in the vagina, but how the availability of this substrate structures the vaginal microbiome is unknown. The effect of host genetics on the maternal microbiome throughout pregnancy is relatively unknown. Different ethnicities, which can be inferred by mitochondrial DNA (mtDNA) haplotypes, have been shown to have varied vaginal microbiomes before and after pregnancy. Further studies are needed to understand these differences, and to explore the effect of host genotype on the maternal microbiome. The impact of diet and obesity on the pregnant microbiome is just beginning to be explored. A primate model of maternal high fat diet showed that diet alone can persistently alter the juvenile microbiome at one year of age regardless of juvenile diet. However, how diet alters the maternal environment during pregnancy and how this affects the vertical transmission of bacteria is unknown.

len et al. 2009). Recently, Romero et al. have performed longitudinal studies of the posterior fornix of the vaginal microbiome during pregnancy using Next-Gen sequencing of the V1V2 region of the 16S rRNA amplicon (Romero et al. 2014b). These studies used the self-collection of vaginal samples over $16 \mathrm{wk}$ of the nonpregnant cohort and swabbing of the posterior fornix at four prenatal visits from the gravid cohort with 22 subjects. Additionally, the gravid cohort consisted of mainly African-American ethnicity. In their analysis, the authors used the CSTs established by Ravel et al. to interrogate the vaginal microbiome during pregnancy (Ravel et al. 2010; Romero et al. 2014b). This study concluded that the vaginal microbiome of gravid wom- 
en mostly consisted of the CST I or III with odds ratios of 2.986 and 2.136, respectively, and that the vaginal microbiome of gravid women shift toward these two CSTs as their pregnancy progressed (Romero et al. 2014b). When the stability of the vaginal microbiome was examined during pregnancy, the authors noted that the vaginal microbiome of gravid subjects shifted between CSTs dominated by lactobacilli but rarely shifted to CST IV, which is marked by a diminished abundance of Lactobacillus species (Romero et al. 2014b). However, with a low number and low ethnic diversity of subjects in the study, further studies are needed to confirm these shifts of the vaginal microbiome toward CSTs dominated by lactobacilli as pregnancy progresses. Initial studies of the vaginal microbiome showed that African-American women have a higher prevalence of vaginal CSTs consisting of Lactobacillus species (Ravel et al. 2010), which was further shown by this recent study (Romero et al. 2014b). In a separate study, the vaginal microbiome was examined longitudinally during gestation using the V3V5 amplicon of $16 \mathrm{~S}$ rRNA in 12 subjects that were mostly Caucasian (Walther-António et al. 2014). In agreement with previous studies, these authors showed that alpha diversity decreases as pregnancy progresses and that $L$. crispatus and L. iners dominate the vaginal microflora (Fig. 2) (Walther-António et al. 2014). Intriguingly, these authors suggest that maternal age may be important for the dominance of $L$. crispatus or $L$. iners, with, $L$. iners being dominant in older gravidae (Walther-António et al. 2014). Although this insight should be kept in mind for future studies, this study had only two subjects with advanced maternal age (34-36) (WaltherAntónio et al. 2014). To take these studies further, this group attempted to analyze their data in conjunction with the Romero et al. study; however, differences in primer sets and sequencing platforms used in these separate studies prevented in depth analysis (Romero et al. 2014b; Walther-António et al. 2014). Despite these challenges, the authors found that, although alpha diversity of the vaginal microbiome decreased with gestational age in both African-American and Caucasian subjects,
African-American subjects had increased beta diversity between gravid subjects whereas Caucasian gravidae did not (Walther-António et al. 2014). Thus, these studies highlight the need for further longitudinal studies with large subject enrollment and ethnic diversity. Additionally, studies are needed with a high enrollment of BV subjects or women with a dysbiotic vaginal microbiome to lend further insight into vaginal microbiome shifts and stability that are associated with pregnancy.

In addition to better understanding shifts in the vaginal microbiome during pregnancy, investigating the microbiome of subjects with $\mathrm{BV}$ may lend insight into the role of the vaginal microbiome in preterm birth. It is known that BV is associated with preterm birth (Martius et al. 1988; Krohn et al. 1991; Hillier et al. 1995a,b), and therefore, it is logical to question the potential association of the vaginal microbiome with preterm birth (Ganu et al. 2013). The Preterm Prediction Study examined the association between $\mathrm{BV}$ and preterm birth (PTB) (Meis et al. 1995). In this study, vaginal specimens were obtained at 24 and 28 wk gestation, and an association with increased risk for spontaneous PTB at $<35$ wk gestation was found in $19.8 \%$ of women with $\mathrm{BV}$ at 28 wk gestation (Meis et al. 1995). However, conclusions could not be drawn regarding whether BV itself was causative of PTB (Meis et al. 1995). Additionally, although treatment of BV during pregnancy does eradicate infection, it does not reduce the risk of PTB (Hillier et al. 1995b; Brocklehurst et al. 2013). Therefore, given the lack of benefit, screening of asymptomatic women in pregnancy is not recommended (Nygren et al. 2008). Even more concerning are the findings of two studies that found an increase in preterm delivery ( $<34 \mathrm{wk}$ ) among women who tested negative for BV but were treated (Hauth et al. 1995; Vermeulen and Bruinse 1999). Thus, the relationship of $\mathrm{BV}$ and preterm birth is complicated and the benefit of treatment is questionable. These issues regarding $\mathrm{BV}$ and $\mathrm{PTB}$ warrant further investigation into these associations, and the examination of the microbiome using Next-Gen sequencing techniques will be of great utility for these studies. 
A.L. Prince et al.

Despite the need for further investigation into the role of the vaginal microbiome in association with BV and preterm birth, a recent study by Hyman et al. (2014) has examined the vaginal microbiome in preterm birth. This group used a prospective cohort study with 46 high-risk (previous unexplained PTB) and 42 low-risk (all other gravid) subjects for PTB gravidae enrolled (Hyman et al. 2014); however, only 14 subjects were able to be sampled in each trimester. Intriguingly, the investigators found that the presence of lactobacilli did not distinguish term $(>37 \mathrm{wk})$ from preterm $(<37 \mathrm{wk})$ subjects using Sanger sequencing methods. However, low-risk subjects had a higher prevalence of lactobacilli when compared with highrisk subjects (Hyman et al. 2014). Despite the lack of association of lactobacilli with preterm birth, measured alpha diversity was reported as diminished when comparing Caucasian term and preterm subjects (Hyman et al. 2014). Among the two longitudinal subjects that ultimately delivered preterm, their vaginal microbiomes were dominated by L. crispatus (Hyman et al. 2014), which is in contrast to a previous study demonstrating that L. crispatus is dominant in healthy term pregnancies (Verstraelen et al. 2009; Aagaard et al. 2012b). Moreover, although two subjects in the Hyman et al. study had outgrowths of Bifidobacterium and Ureaplasma genera, separately, these genera are reported in both normal pregnant subjects as well as nonpregnant (Ravel et al. 2010; Aagaard et al. 2012b; Romero et al. 2014b). Similar findings were found in an independent study by Romero et al. In this prospective study, term (38-32 wk) versus preterm $(<34 \mathrm{wk})$ subjects were sampled at the posterior fornix by an obstetrician and sequenced using V1V3 primers (Romero et al. 2014a). The authors found no association between the CSTs of the vaginal microbiome and preterm birth, nor did they find any CST of the vaginal microbiome associated with preterm subjects having acute chorioamnionitis (Romero et al. 2014a). In contrast to the study by Hyman et al., this study found no significant difference in the alpha diversity of the vaginal microbiome of term and preterm subjects (Hyman et al. 2014; Romero et al. 2014a). In summary, although promising, these studies underscore the need for broader gestational age-specific, reference-based cohorts to define both the effect size and population variance. Before the publication of such studies, it would be premature to ascribe such microbiome profiling as indicative or heralding of preterm birth.

\section{VARIANCE OF THE HUMAN MICROBIOME IN PREGNANCY: BEYOND THE VAGINAL COMMUNITY}

In addition to changes described in the vaginal microbiome during pregnancy, Koren et al. (2012) investigated the intestinal microbiome during pregnancy using a prospective cohort study and found that as pregnancy progressed, the intestinal microbiome was altered. This study used the V1V2 region of the $16 \mathrm{~S}$ rRNA gene and found that alpha diversity (within sample variation) was decreased between the first and third trimesters (Fig. 2). Further, stool samples collected from gravidae in the first trimester clustered separately from stool samples collected in the third trimester (Koren et al. 2012). These differences in beta diversity (between sample variation) were a reflection of increases in Proteobacteria in the stool during the third trimester when compared with stool from the first trimester. When fecal transplants of first and third trimester stool into germ-free mice were performed, mice receiving third trimester stool had increases in inflammatory cytokines and adiposity, similarly to fecal transplants involving obese subjects (Turnbaugh et al. 2006; Koren et al. 2012; Ridaura et al. 2013). These alterations in the intestinal microbiome did not associate with any other covariates, such as body mass index (BMI), development of gestational diabetes mellitus, or multiparity (Koren et al. 2012).

\section{BEYOND THE VAGINAL MICROBIOME: EARLY INFANT COLONIZATION}

Recently, the establishment of the neonatal microbiome has been the subject of debate and investigation. As shown with vaginal micro- 
biome studies, there has been wide variability between the use of techniques and the variable region of $16 \mathrm{~S}$ used for studies. An initial study by Schultz and colleagues examined the vertical transmission of a probiotic, Lactobacillus rhamnosus GG, from mother to infant (Schultz et al. 2004). Gravid women took the probiotic twice daily from 30-36 wk of gestation. The authors found that all infants born vaginally $(4 / 4)$ contained this probiotic in their stool whereas the probiotic was only detected in the stool of half of the cesarean delivered infants $(1 / 2)$ (Schultz et al. 2004). This study showed that vertical transmission did occur between mother and infant. However, this study included a small subject number and did not examine the maternal stool postpartum, which would be relevant to determine the persistence of the probiotic in the maternal microbiome that would provide an opportunity for horizontal transmission. The maternal microbiome during infancy, and not solely delivery mode, may be an important factor in establishing the neonatal microbiome. In fact, a recent study examining the establishment of the intestinal microbiome of healthy, term neonates using qPCR found that bacterial loads between maternal and infant stool were remarkably similar (Jost et al. 2012). This study shows that the maternal microbiome at birth and postpartum may be critical in the establishment and development of the neonatal microbiome via horizontal transmission.

When directly examining the intestinal microbiome of infants born via cesarean or vaginal delivery, culture-based microbiological techniques have shown differences in the colonization of the neonatal intestinal microbiome, particularly of Bifidobacterium-like bacteria, Lactobacillus-like bacteria, and Bacteriodes fragilis (Grönlund et al. 1999a). However, a separate study by this group also determined that bacterial enzymes were not altered in the stool of infants based on mode of delivery (Grönlund et al. 1999b). Using culture-independent, PCRbased techniques, Penders et al. also showed that B. fragilis and Bifidobacterium were decreased in cesarean delivered infants in comparison to vaginally delivered infants. However, this study also showed differences in the intestinal microbiome of infants based on formula-feeding or breastfeeding (Penders et al. 2006). An Italian study further investigated the intestinal microbiome of infants based on mode of delivery using the V6V8 region of the 16S rRNA gene in PCR-DGGE and PCR-temperature gradient gel electrophoresis (TGGE) assays (Biasucci et al. 2008). This group determined that infants born vaginally had increased diversity in their intestinal microbiome when compared with cesarean delivered infants. Again, infants born by cesarean delivery appeared to have an absence of Bifidobacterium in their intestinal microbiome (Biasucci et al. 2008).

To date, few studies on this issue regarding mode of delivery have used Next-Gen sequencing techniques. An initial study was performed in Venezuela with nine gravid subjects, four giving vaginal birth and five having a cesarean delivery (Dominguez-Bello et al. 2010). This study used the V2 region of the $16 \mathrm{~S}$ rRNA gene and showed that the infant microbiome most closely resembled the mothers' vaginal microbiome following vaginal delivery. Similarly, if the infant was born by cesarean delivery, the infant microbiome most closely resembled the skin microbiome (Dominguez-Bello et al. 2010). Furthermore, a Canadian study using NextGen sequencing techniques for the V5, V6, and V7 regions of the 16S rRNA gene showed that Escherichia shigella and Bacteroides were significantly diminished in the intestinal microbiome of infants born by cesarean section (Azad et al. 2013). This study also found that infants with the highest species richness and diversity of their intestinal microbiome were born by emergency cesarean section rather than by an elective cesarean section or vaginally (Azad et al. 2013). However, when followed out to 4 mo postpartum, infants' intestinal microbiome could be differentiated primarily based on mode of feeding. Specifically, infants that were formula-fed had a higher prevalence of Peptostreptococcaceae and Verrucomicrobiaceae when compared with breastfed infants (Azad et al. 2013). Thus, mode of feeding may be more crucial than mode of delivery in regards to the long-term establishment of the microbiome. These findings suggest that the establishment of a stable 
A.L. Prince et al.

microbiome is not only a question of what bacteria are present at birth, but also what factors, either host-derived or environmental, influence the species that persist.

\section{Which Microbiota First Populate the Infant?}

Further studies into the establishment of the neonatal microbiome highlight this principle. Jost et al. (2012) showed that the intestinal microbiome of infants born vaginally and exclusively breastfed decrease the amount of the Firmicutes phylum, of which Lactobacillus belongs, over time while increasing the prevalence of Bacteroides species. Thus, although these infants were born vaginally, a high presence of Firmicutes did not persist. Intriguingly, these vaginally delivered infants could be classified into two cohorts in this study: those that had species of Bacteriodes present in their intestinal microbiome and those that did not (Jost et al. 2012), and this trend was also seen in a separate study (Palmer et al. 2007). This is in contrast to previous studies finding that Bacteroides relative abundance differed based on mode of delivery (Grönlund et al. 1999a; Penders et al. 2006). However, Palmer et al. also determined that variations in the Bacteroides species seen early in neonatal life were less variant and more consistent in the abundance by $1 \mathrm{yr}$ of age. Additionally, the neonatal intestinal microbiome also appeared more adult-like near the end of the first year of life (Palmer et al. 2007). This finding was confirmed in a study by Koenig et al. in which the intestinal microbiome of an infant was monitored for $2.5 \mathrm{yr}$. Here, the authors found that the diversity of the intestinal microbiome increased over time and with the introduction of foods (Koenig et al. 2011). Also, Bacteroides species were found to increase on the introduction of vegetables (Koenig et al. 2011). Altogether, this data indicate that the neonatal microbiome is highly variable within the first year of life. Therefore, various exposures during this time may have a significant impact on the developing microbiome.

Although it is unclear if the health and microbiome of the offspring is persistently influenced by mode of delivery, gestational age at delivery appears to be the greater arbiter for the developing microbiome. For instance, differences in the intestinal microbiome of preterm and term neonates have been described (Schwiertz et al. 2003). In this study, the authors found that healthy, term neonates that were breast fed had increased diversity in their intestinal microbiome when compared with hospitalized, preterm infants using PCR-DGGE analysis (Schwiertz et al. 2003). Additional studies have confirmed that the microbiome of infants with conditions like PTB, very low birth weight infants, or necrotizing enterocolitis, also have an altered microbiome (Schwiertz et al. 2003; Hällström et al. 2004; Milisavljevic et al. 2013; Wang et al. 2013). However, it is unclear if these alterations are caused by early gestational age at delivery or hospitalization because neonatal exposure in early life is pertinent to the establishment of the microbiome.

Furthermore, these exposures at delivery and in early life may have lasting effects on the microbiome (Ding and Schloss 2014; Ma et al. $2014 b$ ). For instance, a recent study showed that breastfeeding has an impact in the long-term enterotype of an individual (Ding and Schloss 2014). This study is bolstered by murine studies suggesting that maternal antibodies transferred via breast milk may have a persistent impact on the intestinal microbiome (Rogier et al. 2014). However, retrospective analysis of the literature determined that mode of delivery may influence obesity in adulthood (Darmasseelane et al. 2014). Thus, these aforementioned associations with mode of feeding and delivery may be attributable to differences in the seeding of the neonatal microbiome. Therefore, future studies are needed to entail how and why microbes remain in distinct body sites. In other words, it may not be a question as to who is there and from whenst and where do they arise, but rather why do certain microbes take up and retain residence? As the maternal diet and microbiome has been shown to influence the establishment and development of the infant microbiome, these future studies may reveal early mechanisms of adult metabolic disorders, which may allow for the early treatment and/or prevention of associated diseases. 


\section{THE PLACENTAL MICROBIOME}

The placenta has long been considered sterile in normal gestation, where the presence of bacteria in clinical cultures is diagnostic for intrauterine infection and a significant risk for PTB (Hillier et al. 1988). The ELGAN studies constituted a large effort that systematically identified bacteria from PTB placentas under this assumption (Olomu et al. 2009; Onderdonk et al. 2008a,b). However, there is increasing recognition of a large discordance between the presence of bacteria as per culture-based diagnoses and clinical outcome (Watts et al. 1992; Pettker et al. 2007; Buhimschi et al. 2009; Han et al. 2009; Leviton et al. 2010; Stout et al. 2013; Combs et al. 2014; Fortner et al. 2014). In fact, the presence of placental or membrane bacteria in the absence of histological infection has been discovered repeatedly over the last few decades (Hillier et al. 1988; Steel et al. 2005; Redline 2007; Stout et al. 2013; Fortner et al. 2014). This has led to the recognition of the need to study and redefine our understanding of the role of intrauterine bacteria in gestation.

One of the earliest studies to recognize the absence of pathogenicity of intrauterine bacteria was performed using histological analysis. It was shown that membranes of normal pregnancies often contain bacteria, yet show no signs of histological infection (Steel et al. 2005). Later studies using similar methodologies discovered intracellular bacteria localized to the trophoblast of the basal plate of the maternal decidua in the absence of chorioamnionitis although there was an association with PTB (Cao and Mysorekar 2013; Stout et al. 2013). Seemingly in agreement, it was also shown that intra-amnionic invasion is relatively benign in the absence of inflammation with associations between PTB and inflammation alone rather than PTB and bacterial invasion (Combs et al. 2014). Intriguing work by Murtha and colleagues showed that high levels of bacteria were strongly associated with premature rupture of membranes (PPROM) and membrane thickness, although there was no histological inflammation in half of the subjects. Although there was bacteria found in subjects of all groups including PPROM (both term and preterm), PTB, and even normal gestation controls, there was no inflammation detected in the majority of subjects (Fortner et al. 2014). Thus, these studies suggest that it is not the occurrence of bacteria in the placenta, but the bacterial populations present that may initiate intrauterine infection.

Along these lines, a metagenomic study using a Rhesus macaque model identified more than 300 microbial species in the chorioamnion and placenta (Aagaard et al. 2013). Interestingly, it was shown that this population was modifiable with a sterile intra-amniotic injection of IL-1 $\beta$ that induced histological inflammation (Aagaard et al. 2013). This suggests that chorioamnionitis may be caused by microbial dysbiosis rather than the presence of bacteria per se. The potential translational implications of this model to human pregnancy was emphasized recently by our description of a vibrant and diverse commensal placental microbiome in normal pregnancies (Aagaard et al. 2014). Analysis of more than 300 human samples using both $16 \mathrm{~S}$ and WGS sequencing revealed a low abundance complex community dominated by the phyla Firmicutes, Tenericutes, Proteobacteria, Bacteroidetes, and Fusobacteria, found in nearly all samples. Subjects with a remote history of antenatal infection and antibiotic treatment, or who developed PTB, had discrete statistically significant groupings of taxa (Aagaard et al. 2014). It was also found that the placental microbiome most closely resembles the oral microbiomes of the supragingival plaque and the dorsum of the tongue; however, the placental microbiome did not closely resemble the stool or the vaginal microbiomes. This implies that the bulk of the low level placental bacteria are likely not ascending nor are contaminants of the stool or the vagina, and instead, are quite possibly seeded largely from the oral cavity through hematogenous spread (Fig. 3).

The entering of oral microbes into the blood stream as a result of periodontitis or dental procedures is well established (Han and Wang 2013), and it has been known for decades that periodontal disease is linked to PTB (Offenbacher et al. 1996, 2009; Goldenberg et al. 
A.L. Prince et al.

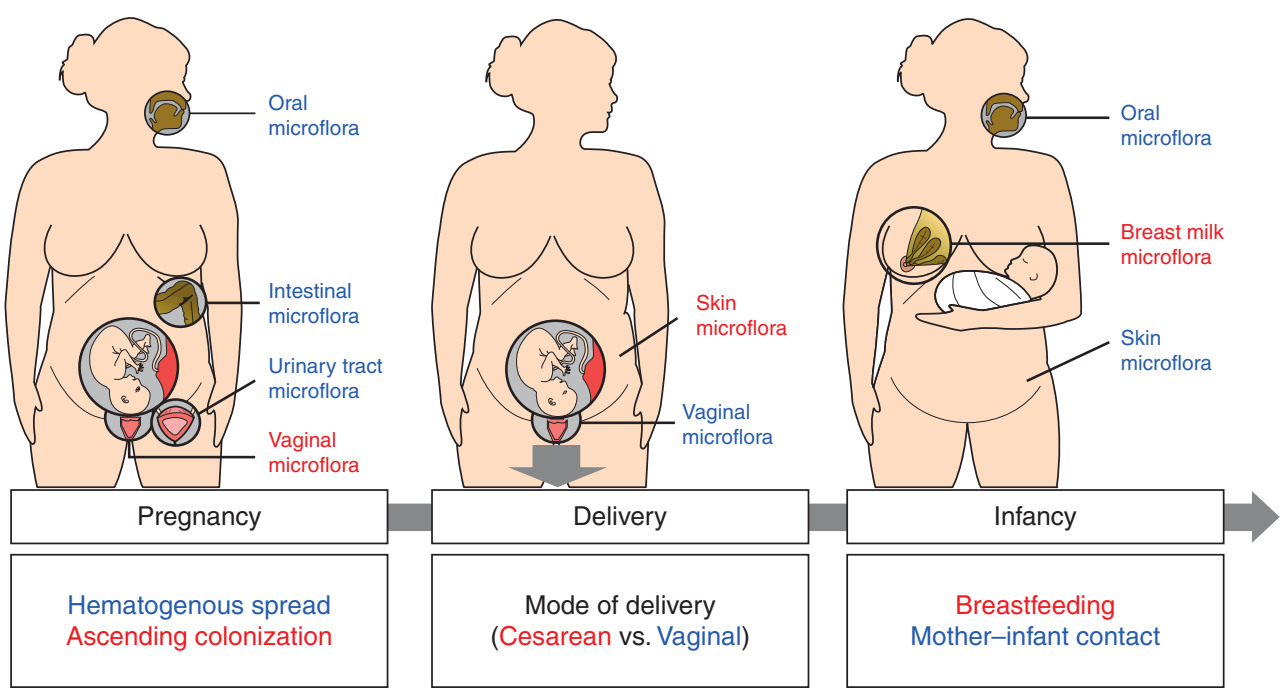

Figure 3. Speculated origins for microbiota colonizing the placenta and seeding the initial neonatal microbiome. Vaginal microflora likely contribute to the initial seeding of the neonatal microbiome during vaginal deliveries, but the discovery that the uterine environment may not be sterile suggests that colonization of the infant may happen before birth. Recent data demonstrating that the placenta has its own unique microbiome most closely resembling the oral microbiome suggests a potential hematogenous route by which bacteria can seed the placenta and the developing fetus. Microbiota from maternal oral, vaginal, urinary tract, and intestine are all potential sources for these colonizing bacteria. Microbiota from breast milk and maternal contact may be an important source of commensal bacteria during early infancy and must be considered when studying the microflora of the neonate.

2000; Michalowicz et al. 2006; Macones et al. 2010). Animal models have shown that bacteria may be spread hematogenously to the placenta (Han et al. 2004; Fardini et al. 2010), and reports have suggested that oral bacteria may be associated with pregnancy complications (Katz et al. 2009; Han et al. 2010; Swati et al. 2012). Fusobacterium nucleatum is an oral pathogen that is frequently found in diagnostic cultures following PTB, PPROM, and stillbirth (Romero et al. 1989; Watts et al. 1992; Han et al. 2004, 2010; Cahill et al. 2005). Our finding of Fusobacteria to be a relatively abundant taxon in the placenta supports the hypothesis of hematogenous spread from the oral cavity to the placenta (Aagaard et al. 2014), and this theory is further buttressed by the finding of bacteria in cord blood of normal pregnancies (Jiménez et al. 2005). Along these lines, bacteria can spread from the intra-amnion outward to the chorion, which indicates that hematogenous spread from mother to infant may be occurring via cord blood (Kim et al. 2009). Thus, hematogenous spread may promote colonization of the placenta and the fetus, but further studies are needed to examine this phenomenon. However, a potential mechanism to compromise the maternal-fetal barrier has been illuminated. In a mechanism akin to Listeria monocytogenes (Bakardjiev et al. 2006; Le Monnier et al. 2007), F. nucleatum expresses adhesin FadA that interacts with E-cadherin, which compromises cell-cell adhesion and membranes (Lecuit et al. 2004; Ikegami et al. 2009; Fardini et al. 2011). However, further studies are necessary to show definitively that hematogenous spread from the oral cavity is possible for colonization or infection of the placenta.

Ongoing and future study of the complex origins of neonatal bacteria should consider oral and placental microbiomes in addition to the vaginal microflora. This need is exemplified by studies involving infants born preterm with early-onset neonatal sepsis showing the pres- 
ence of Fusobacterium, Ureaplasma, and Mycoplasma in the cord blood, amniotic fluid, and neonatal blood (Wang et al. 2013). Additionally, neonates with late onset sepsis or necrotizing enterocolitis have been found to have intestinal microbial dysbiosis that precedes clinical diagnosis (Mai et al. 2011, 2013). Although the vaginal microbiome may be implicated in these neonatal diseases, significant differences in the abundance of placental bacteria have been found when comparing preterm and term placentas (Jones et al. 2009; Stout et al. 2013; Aagaard et al. 2014). Thus, we speculate that seeding of the neonatal microbiome with bacteria from the placenta, which arose through hematogenous spread, may facilitate early colonization. Thus, this early colonization in combination with variable, modifying host factors (King et al. 2007; Zeldovich and Bakardjiev 2012) may conceivably provide the initial seeding of a dysbiotic microbiome that may render susceptibility to neonatal disease in a preterm or stressed infant.

\section{CONCLUSIONS AND CLINICAL SIGNIFICANCE}

Here we have described the current state of the science on several aspects of the female reproductive microbiome, as well as their current association with perinatal disorders of both the mother and her offspring. What we understand today is far more complex and confounded than was appreciated less than a decade ago, and is much simpler than what we will come to realize in coming years. The vaginal microbiome varies from one woman to the next, across the lifespan, and in association with both health and disease states. Simplified views of "less diversity and less rich vaginal microbiomes are equivalent to disease states" have been challenged and discounted, and concepts of clearly delineated CSTs remain to be fully validated. Previously assumed to be "sterile" reproductive tract tissues have been shown to harbor low biomass microbiomes, and yet we remain unclear as to what, how and when the infant is colonized. What will serve as decisive determinants of community structure is still unknown, and the relative in- fluence of antibiotics, prebiotics, and probiotics (as well as early in life diet and exogenous exposures) has yet to be robustly characterized. A systemic analysis of the microbiome across the reproductive health spectrum (adolescence, pregnancy, postnatal and perimenopausal/ menopausal/postmenopausal) will undoubtedly shed light on the most significant and perplexing common disorders of our time. Although this is a challenging area of research, the advent of metagenomics, combined with integrative multi'omics, will enable reproductive scientists and physician scientists to unravel the mysteries plaguing not only our generations' health and disease, but will likely shed light on human and primate coevolution of host and microbe.

\section{ACKNOWLEDGMENTS}

This research was supported in part by a grant to Baylor College of Medicine from the Howard Hughes Medical Institute through the Med into Grad Initiative. For financial support, the authors acknowledge the National Institutes of Health (NIH) Director's New Innovator Award (K.A., DP2 DP21DP2OD001500), the Burroughs Wellcome Fund Preterm Birth Initiative (K.A., 1008819.01), the National Institute of Nursing Research Grant (K.A., R01NR014792), National Institute of General Medical Sciences (T32GM088129), Medical Scientist Training Program (T32GM007330), and the Human Microbiome Project funded through the NIH Director's Common Fund at the National Institutes of Health (as part of NIH RoadMap 1.5).

\section{REFERENCES}

Aagaard K, Petrosino J, Keitel W, Watson M, Katancik J, Garcia N, Patel S, Cutting M, Madden T, Hamilton H, et al. 2012a. The Human Microbiome Project strategy for comprehensive sampling of the human microbiome and why it matters. FASEB J 27: 1012-1022.

Aagaard K, Riehle K, Ma J, Segata N, Mistretta T-A, Coarfa C, Raza S, Rosenbaum S, Van den Veyver I, Milosavljevic A, et al. 2012b. A metagenomic approach to characterization of the vaginal microbiome signature in pregnancy. PLoS ONE 7: e36466. 
A.L. Prince et al.

Aagaard K, Ganu R, Ma J, Hu M, Miller L, Jobe A, Kallapur S, Chougnet C. 2013. 506: Intraamniotic interleukin-1 (IL1 $\beta$ ) induces histologic chorioamnionitis and alters the microbiome in a primate model of inflammatory preterm birth. Am J Obstet Gynecol 208: S218.

Aagaard K, Ma J, Antony KM, Ganu R, Petrosino J, Versalovic J. 2014. The placenta harbors a unique microbiome. Sci Transl Med 6: 237ra65.

Abubucker S, Segata N, Goll J, Schubert AM, Izard J, Cantarel BL, Rodriguez-Mueller B, Zucker J, Thiagarajan M, Henrissat B, et al. 2012. Metabolic reconstruction for metagenomic data and its application to the human microbiome. PLoS Comput Biol 8: e1002358.

Azad MB, Konya T, Maughan H, Guttman DS, Field CJ, Chari RS, Sears MR, Becker AB, Scott JA, Kozyrskyj AL. 2013. Gut microbiota of healthy Canadian infants: Profiles by mode of delivery and infant diet at 4 months. CMAJ 185: 385-394.

Bäckhed F, Manchester JK, Semenkovich CF, Gordon JI. 2007. Mechanisms underlying the resistance to diet-induced obesity in germ-free mice. Proc Natl Acad Sci 104: 979-984.

Bakardjiev AI, Theriot JA, Portnoy DA. 2006. Listeria monocytogenes traffics from maternal organs to the placenta and back. PLoS Pathog 2: e66.

Biasucci G, Benenati B, Morelli L, Bessi E, Boehm G. 2008. Cesarean delivery may affect the early biodiversity of intestinal bacteria. J Nutr 138: 1796S-1800S.

Booijink CCGM, Boekhorst J, Zoetendal EG, Smidt H, Kleerebezem M, de Vos WM. 2010. Metatranscriptome analysis of the human fecal microbiota reveals subjectspecific expression profiles, with genes encoding proteins involved in carbohydrate metabolism being dominantly expressed. Appl Environ Microbiol 76: 5533-5540.

Boskey ER, Telsch KM, Whaley KJ, Moench TR, Cone RA. 1999. Acid production by vaginal flora in vitro is consistent with the rate, extent of vaginal acidification. Infect Immun 67: 5170-5175.

Boskey ER, Cone RA, Whaley KJ, Moench TR. 2001. Origins of vaginal acidity: High $\mathrm{D} / \mathrm{L}$ lactate ratio is consistent with bacteria being the primary source. Hum Reprod 16: $1809-1813$.

Brocklehurst P, Gordon A, Heatley E, Heatley E, Milan SJ. 2013. Antibiotics for treating bacterial vaginosis in pregnancy. Cochrane Database Syst Rev 1: CD000262.

Brotman RM, Klebanoff MA, Nansel TR, Yu KF, Andrews WW, Zhang J, Schwebke JR. 2010. Bacterial vaginosis assessed by gram stain and diminished colonization resistance to incident gonococcal, chlamydial, and trichomonal genital infection. J Infect Dis 202: 1907-1915.

Buhimschi CS, Dulay AT, Abdel-Razeq S, Zhao G, Lee S, Hodgson EJ, Bhandari V, Buhimschi IA. 2009. Fetal inflammatory response in women with proteomic biomarkers characteristic of intra-amniotic inflammation and preterm birth. BJOG 116: 257-267.

Butler J, Maccallum I, Kleber M, Shlyakhter IA, Belmonte MK, Lander ES, Nusbaum C, Jaffe DB. 2008. ALLPATHS: De novo assembly of whole-genome shotgun microreads. Genome Res 18: 810-820.

Cahill RJ, Tan S, Dougan G, O'Gaora P, Pickard D, Kennea N, Sullivan MHF, Feldman RG, Edwards AD. 2005. Universal DNA primers amplify bacterial DNA from human fetal membranes and link Fusobacterium nucleatum with prolonged preterm membrane rupture. Mol Hum Reprod 11: 761-766.

Cani PD, Neyrinck AM, Fava F, Knauf C, Burcelin RG, Tuohy KM, Gibson GR, Delzenne NM. 2007. Selective increases of bifidobacteria in gut microflora improve high-fat-diet-induced diabetes in mice through a mechanism associated with endotoxaemia. Diabetologia 50: 2374-2383.

Cao B, Mysorekar IU. 2013. Intracellular bacteria in placental basal plate localize to extravillous trophoblasts. Placenta 35: 139-142.

Caporaso JG, Kuczynski J, Stombaugh J, Bittinger K, Bushman FD, Costello EK, Fierer N, Peña AG, Goodrich JK, Gordon JI, et al. 2010. QIIME allows analysis of highthroughput community sequencing data. Nat Methods 7: 335-336.

Claud EC, Walker WA. 2001. Hypothesis: Inappropriate colonization of the premature intestine can cause neonatal necrotizing enterocolitis. FASEB J 15: 1398-1403.

Combs CA, Gravett M, Garite TJ, Hickok DE, Lapidus J, Porreco R, Rael J, Grove T, Morgan TK, Clewell W, et al. 2014. Amniotic fluid infection, inflammation, and colonization in preterm labor with intact membranes. Am J Obstet Gynecol 210: 125.e1-125.e15.

Darmasseelane K, Hyde MJ, Santhakumaran S, Gale C, Modi N. 2014. Mode of delivery and offspring body mass index, overweight and obesity in adult life: A systematic review and meta-analysis. PLoS ONE 9: e87896.

DeSantis TZ, Hugenholtz P, Larsen N, Rojas M, Brodie EL, Keller K, Huber T, Dalevi D, Hu P, Andersen GL. 2006. Greengenes, a chimera-checked 16S rRNA gene database and workbench compatible with ARB. Appl Environ Microbiol 72: 5069-5072.

Devaraj S, Hemarajata P, Versalovic J. 2013. The human gut microbiome and body metabolism: Implications for obesity and diabetes. Clin Chem 59: 617-628.

Ding T, Schloss PD. 2014. Dynamics and associations of microbial community types across the human body. Nature 509: 357-360.

Dominguez-Bello MG, Costello EK, Contreras M, Magris M, Hidalgo G, Fierer N, Knight R. 2010. Delivery mode shapes the acquisition and structure of the initial microbiota across multiple body habitats in newborns. Proc Natl Acad Sci 107: 11971-11975.

Eschenbach DA. 1993. History and review of bacterial vaginosis. Am J Obstet Gynecol 169: 441-445.

Eschenbach DA, Davick PR, Williams BL, Klebanoff SJ, Young-Smith K, Critchlow CM, Holmes KK. 1989. Prevalence of hydrogen peroxide-producing Lactobacillus species in normal women and women with bacterial vaginosis. J Clin Microbiol 27: 251-256.

Fardini Y, Chung P, Dumm R, Joshi N, Han YW. 2010. Transmission of diverse oral bacteria to murine placenta: Evidence for the oral microbiome as a potential source of intrauterine infection. Infect Immun 78: 1789-1796.

Fardini Y, Wang X, Témoin S, Nithianantham S, Lee D, Shoham M, Han YW. 2011. Fusobacterium nucleatum adhesin FadA binds vascular endothelial cadherin and alters endothelial integrity. Mol Microbiol 82: 1468-1480. 
Faro S, Martens M, Maccato M, Hammill H, Pearlman M. 1993. Vaginal flora and pelvic inflammatory disease. Am J Med 333: 1732-1736.

Faust K, Sathirapongsasuti JF, Izard J, Segata N, Gevers D, Raes J, Huttenhower C. 2012. Microbial co-occurrence relationships in the human microbiome. PLoS Comput Biol 8: e1002606.

Fettweis JM, Serrano MG, Sheth NU, Mayer CM, Glascock AL, Brooks JP, Jefferson KK, Buck GA. 2012. Species-level classification of the vaginal microbiome. BMC Genomics 13: S17.

Fortner KB, Grotegut CA, Ransom CE, Bentley RC, Feng L, Lan L, Heine RP, Seed PC, Murtha AP. 2014. Bacteria localization and chorion thinning among preterm premature rupture of membranes. PLOS ONE 9: e83338.

Gajer P, Brotman RM, Bai G, Sakamoto J, Schutte UME, Zhong X, Koenig SSK, Fu L, Ma Z, Zhou X, et al. 2012. Temporal dynamics of the human vaginal microbiota. $S c i$ Transl Med 4: 132ra52.

Ganu RS, Ma J, Aagaard KM. 2013. The role of microbial communities in parturition: Is there evidence of association with preterm birth and perinatal morbidity and mortality? Am J Perinatol 30: 613-624.

Gevers D, Knight R, Petrosino JF, Huang K, McGuire AL, Birren BW, Nelson KE, White O, Methé BA, Huttenhower C. 2012. The Human Microbiome Project: A community resource for the healthy human microbiome. PLoS Biol 10: e1001377.

Ghartey JP, Smith BC, Chen Z, Buckley N, Lo Y, Ratner AJ, Herold BC, Burk RD. 2014. Lactobacillus crispatus dominant vaginal microbiome is associated with inhibitory activity of female genital tract secretions against Escherichia coli. PLoS ONE 9: e96659.

Glass EM, Wilkening J, Wilke A, Antonopoulos D, Meyer F. 2010. Using the metagenomics RAST server (MG-RAST) for analyzing shotgun metagenomes. Cold Spring Harb Protoc doi: $10.1101 /$ pdb.prot5368.

Goldenberg RL, Hauth JC, Andrews WW. 2000. Intrauterine infection and preterm delivery. $N$ Engl J Med 342: 15001507.

Gonçalves LF, Chaiworapongsa T, Romero R. 2002. Intrauterine infection and prematurity. Ment Retard Dev Disabil Res Rev 8: 3-13.

Gophna U, Sommerfeld K, Gophna S, Doolittle WF, Veldhuyzen van Zanten SJO. 2006. Differences between tissue-associated intestinal microfloras of patients with Crohn's disease and ulcerative colitis. J Clin Microbiol 44: 4136-4141.

Gosalbes MJ, Durbán A, Pignatelli M, Abellan JJ, JiménezHernández N, Pérez-Cobas AE, Latorre A, Moya A. 2011. Metatranscriptomic approach to analyze the functional human gut microbiota. PLOS ONE 6: e17447.

Gravett MG, Nelson HP, DeRouen T, Critchlow C, Eschenbach DA, Holmes KK. 1986. Independent associations of bacterial vaginosis and Chlamydia trachomatis infection with adverse pregnancy outcome. JAMA 256: 1899 1903.

Gregoire AT, Kandil O, Ledger WJ. 1971. The glycogen content of human vaginal epithelial tissue. Fertil Steril 22: 64-68.
Grönlund MM, Lehtonen OP, Eerola E, Kero P. 1999a. Fecal microflora in healthy infants born by different methods of delivery: Permanent changes in intestinal flora after cesarean delivery. J Pediatr Gastroenterol Nutr 28: 19-25.

Grönlund MM, Salminen S, Mykkänen H, Kero P, Lehtonen OP. 1999b. Development of intestinal bacterial enzymes in infants-Relationship to mode of delivery and type of feeding. APMIS 107: 655-660.

Guthrie SO, Gordon PV, Thomas V, Thorp JA, Peabody J, Clark RH. 2003. Necrotizing enterocolitis among neonates in the United States. J Perinatol 23: 278-285.

Hällström M, Eerola E, Vuento R, Janas M, Tammela O. 2004. Effects of mode of delivery and necrotising enterocolitis on the intestinal microflora in preterm infants. Eur J Clin Microbiol Infect Dis 23: 463-470.

Han YW, Wang X. 2013. Mobile microbiome: Oral bacteria in extra-oral infections and inflammation. J Dent Res 92: $485-491$.

Han YW, Redline RW, Li M, Yin L, Hill GB, McCormick TS. 2004. Fusobacterium nucleatum induces premature and term stillbirths in pregnant mice: Implication of oral bacteria in preterm birth. Infect Immun 72: 2272-2279.

Han YW, Shen T, Chung P, Buhimschi IA, Buhimschi CS. 2009. Uncultivated bacteria as etiologic agents of intraamniotic inflammation leading to preterm birth. J Clin Microbiol 47: 38-47.

Han YW, Fardini Y, Chen C, Iacampo KG, Peraino VA, Shamonki JM, Redline RW. 2010. Term stillbirth caused by oral Fusobacterium nucleatum. Obstet Gynecol 115: $442-$ 445.

Hauth JC, Goldenberg RL, Andrews WW, DuBard MB, Copper RL. 1995. Erythromycin in women with bacterial vaginosis. N Engl J Med 333: 1732-1736.

Hernández-Rodríguez C, Romero-González R, AlbaniCampanario M, Figueroa-Damián R, Meraz-Cruz N, Hernández-Guerrero C. 2011. Vaginal microbiota of healthy pregnant Mexican women is constituted by four Lactobacillus species and several vaginosis-associated bacteria. Infect Dis Obstet Gynecol 2011: 851485.

Hillier SL, Martius J, Krohn M, Kiviat N, Holmes KK, Eschenbach DA. 1988. A case-control study of chorioamnionic infection and histologic chorioamnionitis in prematurity. N Engl J Med 319: 972-978.

Hillier SL, Krohn MA, Klebanoff SJ, Eschenbach DA. 1992. The relationship of hydrogen peroxide-producing lactobacilli to bacterial vaginosis and genital microflora in pregnant women. Obstet Gynecol 79: 369-373.

Hillier SL, Krohn MA, Rabe LK, Klebanoff SJ, Eschenbach DA. 1993. The normal vaginal flora, $\mathrm{H}_{2} \mathrm{O}_{2}$-producing lactobacilli, and bacterial vaginosis in pregnant women. Clin Infect Dis 16: S273-S281.

Hillier SL, Krohn MA, Cassen E, Easterling TR, Rabe LK, Eschenbach DA. 1995a. The role of bacterial vaginosis and vaginal bacteria in amniotic fluid infection in women in preterm labor with intact fetal membranes. Clin Infect Dis 20: S276-S278.

Hillier SL, Nugent RP, Eschenbach DA, Krohn MA, Gibbs RS, Martin DH, Cotch MF, Edelman R, Pastorek JG, Rao AV. 1995b. Association between bacterial vaginosis and preterm delivery of a low-birth-weight infant. The Vaginal Infections and Prematurity Study Group. N Engl J Med 333: 1737-1742. 
A.L. Prince et al.

Human Microbiome Project. 2012a. A framework for human microbiome research. Nature 486: 215-221.

Human Microbiome Project. 2012b. Evaluation of 16S rDNA-based community profiling for human microbiome research. PLoS ONE 7: e39315.

Human Microbiome Project. 2012c. Structure, function and diversity of the healthy human microbiome. Nature 486: 207-214.

Hummelen R, Fernandes AD, Macklaim JM, Dickson RJ, Changalucha J, Gloor GB, Reid G. 2010. Deep sequencing of the vaginal microbiota of women with HIV. PLoS ONE 5: e12078.

Huse SM, Ye Y, Zhou Y, Fodor AA. 2012. A core human microbiome as viewed through $16 \mathrm{~S}$ rRNA sequence clusters. PLOS ONE 7: e34242.

Hyman RW, Fukushima M, Jiang H, Fung E, Rand L, Johnson B, Vo KC, Caughey AB, Hilton JF, Davis RW, et al. 2014. Diversity of the vaginal microbiome correlates with preterm birth. Reprod Sci 21: 32-40.

Ikegami A, Chung P, Han YW. 2009. Complementation of the fadA mutation in Fusobacterium nucleatum demonstrates that the surface-exposed adhesin promotes cellular invasion and placental colonization. Infect Immun 77: 3075-3079.

Jiménez E, Fernández L, Marín ML, Martín R, Odriozola JM, Nueno-Palop C, Narbad A, Olivares M, Xaus J, Rodríguez JM. 2005. Isolation of commensal bacteria from umbilical cord blood of healthy neonates born by cesarean section. Curr Microbiol 51: 270-274.

Jonasson J, Olofsson M, Monstein H-J. 2007. Classification, identification and subtyping of bacteria based on pyrosequencing and signature matching of $16 \mathrm{~s}$ rDNA fragments. 2002. APMIS 115: 678-679.

Jones HE, Harris KA, Azizia M, Bank L, Carpenter B, Hartley JC, Klein N, Peebles D. 2009. Differing prevalence and diversity of bacterial species in fetal membranes from very preterm and term labor. PLoS ONE 4: e8205.

Joossens M, Huys G, Cnockaert M, De Preter V, Verbeke K, Rutgeerts P, Vandamme P, Vermeire S. 2011. Dysbiosis of the faecal microbiota in patients with Crohn's disease and their unaffected relatives. Gut 60: 631-637.

Jost T, Lacroix C, Braegger CP, Chassard C. 2012. New insights in gut microbiota establishment in healthy breast fed neonates. PLoS ONE 7: e44595.

Katz J, Chegini N, Shiverick KT, Lamont RJ. 2009. Localization of $P$. gingivalis in preterm delivery placenta. J Dent Res 88: $575-578$.

Kim MJ, Romero R, Gervasi MT, Kim J-S, Yoo W, Lee D-C, Mittal P, Erez O, Kusanovic JP, Hassan SS, et al. 2009. Widespread microbial invasion of the chorioamniotic membranes is a consequence and not a cause of intraamniotic infection. Lab Invest 89: 924-936.

King AE, Paltoo A, Kelly RW, Sallenave J-M, Bocking AD, Challis JRG. 2007. Expression of natural antimicrobials by human placenta and fetal membranes. Placenta 28: 161-169.

Klebanoff SJ, Coombs RW. 1991. Viricidal effect of Lactobacillus acidophilus on human immunodeficiency virus type 1: Possible role in heterosexual transmission. J Exp Med 174: 289-292.
Klebanoff SJ, Hillier SL, Eschenbach DA, Waltersdorph AM. 1991. Control of the microbial flora of the vagina by $\mathrm{H}_{2} \mathrm{O}_{2}$-generating lactobacilli. J Infect Dis 164: 94-100.

Klindworth A, Pruesse E, Schweer T, Peplies J, Quast C, Horn M, Glöckner FO. 2013. Evaluation of general 16S ribosomal RNA gene PCR primers for classical and nextgeneration sequencing-based diversity studies. Nucleic Acids Res 41: e1.

Koenig JE, Spor A, Scalfone N, Fricker AD, Stombaugh J, Knight R, Angenent LT, Ley RE. 2011. Succession of microbial consortia in the developing infant gut microbiome. Proc Natl Acad Sci 108: 4578-4585.

Koren O, Goodrich JK, Cullender TC, Spor A, Laitinen K, Bäckhed HK, Gonzalez A, Werner JJ, Angenent LT, Knight $\mathrm{R}$, et al. 2012. Host remodeling of the gut microbiome and metabolic changes during pregnancy. Cell 150: 470480.

Koren O, Knights D, Gonzalez A, Waldron L, Segata N, Knight R, Huttenhower C, Ley RE. 2013. A guide to enterotypes across the human body: Meta-analysis of microbial community structures in human microbiome datasets. PLoS Comput Biol 9: e1002863.

Krohn MA, Hillier SL, Lee ML, Rabe LK, Eschenbach DA. 1991. Vaginal Bacteroides species are associated with an increased rate of preterm delivery among women in preterm labor. J Infect Dis 164: 88-93.

Kurki T, Sivonen A, Renkonen OV, Savia E, Ylikorkala O. 1992. Bacterial vaginosis in early pregnancy and pregnancy outcome. Obstet Gynecol 80: 173-177.

Larsen B, Monif GR. 2001. Understanding the bacterial flora of the female genital tract. Clin Infect Dis 32: e69-e77.

Larsen N, Vogensen FK, van den Berg FWJ, Nielsen DS, Andreasen AS, Pedersen BK, Al-Soud WA, Sørensen SJ, Hansen LH, Jakobsen M. 2010. Gut microbiota in human adults with type 2 diabetes differs from non-diabetic adults. PLoS ONE 5: e9085.

Lecuit M, Nelson DM, Smith SD, Khun H, Huerre M, Vacher-Lavenu M-C, Gordon JI, Cossart P. 2004. Targeting and crossing of the human maternofetal barrier by Listeria monocytogenes: Role of internalin interaction with trophoblast E-cadherin. Proc Natl Acad Sci 101: 6152-6157.

Ledger WJ. 1993. Historical review of the treatment of bacterial vaginosis. Am J Obstet Gynecol 169: 474-478.

Lepage P, Häsler R, Spehlmann ME, Rehman A, Zvirbliene A, Begun A, Ott S, Kupcinskas L, Doré J, Raedler A, et al. 2011. Twin study indicates loss of interaction between microbiota and mucosa of patients with ulcerative colitis. Gastroenterology 141: 227-236.

Leviton A, Allred EN, Kuban KCK, Hecht JL, Onderdonk AB, O'shea TM, Paneth N. 2010. Microbiologic and histologic characteristics of the extremely preterm infant's placenta predict white matter damage and later cerebral palsy. The ELGAN study. Pediatr Res 67: 95-101.

Ley RE, Bäckhed F, Turnbaugh P, Lozupone CA, Knight RD, Gordon JI. 2005. Obesity alters gut microbial ecology. Proc Natl Acad Sci 102: 11070-11075.

Li K, Bihan M, Yooseph S, Methé BA. 2012. Analyses of the microbial diversity across the human microbiome. PLoS ONE 7: e32118. 
Liu Z, Lozupone C, Hamady M, Bushman FD, Knight R. 2007. Short pyrosequencing reads suffice for accurate microbial community analysis. Nucleic Acids Res 35: e120.

Liu B, Faller LL, Klitgord N, Mazumdar V, Ghodsi M, Sommer DD, Gibbons TR, Treangen TJ, Chang Y-C, Li S, et al. 2012. Deep sequencing of the oral microbiome reveals signatures of periodontal disease. PLOS ONE 7: e37919.

Ma J, Coarfa C, Qin X, Bonnen PE, Milosavljevic A, Versalovic J, Aagaard K. 2014a. mtDNA haplogroup and single nucleotide polymorphisms structure human microbiome communities. BMC Genomics 15: 257.

Ma J, Prince AL, Bader D, Hu M, Ganu R, Baquero K, Blundell P, Alan Harris R, Frias AE, Grove KL, et al. 2014b. High-fat maternal diet during pregnancy persistently alters the offspring microbiome in a primate model. Nat Commun 5: 3889.

Macklaim JM, Fernandes AD, Di Bella JM, Hammond J-A, Reid G, Gloor GB. 2013. Comparative meta-RNA-seq of the vaginal microbiota and differential expression by Lactobacillus iners in health and dysbiosis. Microbiome 1: 12 .

Macones GA, Parry S, Nelson DB, Strauss JF, Ludmir J, Cohen AW, Stamilio DM, Appleby D, Clothier B, Sammel MD, et al. 2010. Treatment of localized periodontal disease in pregnancy does not reduce the occurrence of preterm birth: Results from the Periodontal Infections and Prematurity Study (PIPS). Am J Obstet Gynecol 202: 147.e1-147.e8.

Mai V, Young CM, Ukhanova M, Wang X, Sun Y, Casella G, Theriaque D, Li N, Sharma R, Hudak M, et al. 2011. Fecal microbiota in premature infants prior to necrotizing enterocolitis. PLoS ONE 6: e20647.

Mai V, Torrazza RM, Ukhanova M, Wang X, Sun Y, Li N, Shuster J, Sharma R, Hudak ML, Neu J. 2013. Distortions in development of intestinal microbiota associated with late onset sepsis in preterm infants. PLoS ONE 8: e52876.

Mangin I, Bonnet R, Seksik P, Rigottier-Gois L, Sutren M, Bouhnik Y, Neut C, Collins MD, Colombel J-F, Marteau P, et al. 2004. Molecular inventory of faecal microflora in patients with Crohn's disease. FEMS Microbiol Ecol 50: 25-36.

Manichanh C, Rigottier-Gois L, Bonnaud E, Gloux K, Pelletier E, Frangeul L, Nalin R, Jarrin C, Chardon P, Marteau P, et al. 2006. Reduced diversity of faecal microbiota in Crohn's disease revealed by a metagenomic approach. Gut 55: 205-211.

Marchesi JR, Dutilh BE, Hall N, Peters WHM, Roelofs R, Boleij A, Tjalsma H. 2011. Towards the human colorectal cancer microbiome. PLoS ONE 6: e20447.

Martin HL, Richardson BA, Nyange PM, Lavreys L, Hillier SL, Chohan B, Mandaliya K, Ndinya-Achola JO, Bwayo J, Kreiss J. 1999. Vaginal lactobacilli, microbial flora, and risk of human immunodeficiency virus type 1 and sexually transmitted disease acquisition. J Infect Dis 180: $1863-1868$.

Martius J, Krohn MA, Hillier SL, Stamm WE, Holmes KK, Eschenbach DA. 1988. Relationships of vaginal Lactobacillus species, cervical Chlamydia trachomatis, and bacterial vaginosis to preterm birth. Obstet Gynecol 71: 89-95.

McHardy IH, Goudarzi M, Tong M, Ruegger PM, Schwager E, Weger JR, Graeber TG, Sonnenburg JL, Horvath S,
Huttenhower C, et al. 2013. Integrative analysis of the microbiome and metabolome of the human intestinal mucosal surface reveals exquisite inter-relationships. Microbiome 1: 17.

Meis PJ, Goldenberg RL, Mercer B, Moawad A. 1995. The preterm prediction study: Significance of vaginal infections. Am J Obstet Gynecol 173: 1231-1235.

Michalowicz BS, Hodges JS, DiAngelis AJ, Lupo VR, Novak MJ, Ferguson JE, Buchanan W, Bofill J, Papapanou PN, Mitchell DA, et al. 2006. Treatment of periodontal disease and the risk of preterm birth. N Engl J Med 355: 1885 1894.

Milisavljevic V, Garg M, Vuletic I, Miller JF, Kim L, Cunningham TD, Schröder I. 2013. Prospective assessment of the gastroesophageal microbiome in VLBW neonates. BMC Pediatr 13: 49.

Le Monnier A, Autret N, Join-Lambert OF, Jaubert F, Charbit A, Berche P, Kayal S. 2007. ActA is required for crossing of the fetoplacental barrier by Listeria monocytogenes. Infect Immun 75: 950-957.

Morgan XC, Huttenhower C. 2014. Meta'omic analytic techniques for studying the intestinal microbiome. Gastroenterology 146: 1437-1448.e1.

Morgan XC, Tickle TL, Sokol H, Gevers D, Devaney KL, Ward DV, Reyes JA, Shah SA, LeLeiko N, Snapper SB, et al. 2012. Dysfunction of the intestinal microbiome in inflammatory bowel disease and treatment. Genome Biol 13: R79.

Ness RB, Kip KE, Soper DE, Hillier S, Stamm CA, Sweet RL, Rice P, Richter HE. 2005. Bacterial vaginosis (BV) and the risk of incident gonococcal or chlamydial genital infection in a predominantly black population. Sex Transm Dis 32: 413-417.

Nieburgs HE. 1947. Gestational changes in the vaginal epithelium and their relation to the sex of the foetus. J Obstet Gynaecol Br Emp 54: 653-655.

Nygren P, Fu R, Freeman M, Bougatsos C, Klebanoff M, Guise J-M. 2008. Evidence on the benefits and harms of screening and treating pregnant women who are asymptomatic for bacterial vaginosis: An update review for the U.S. Preventive Services Task Force. Ann Intern Med 148: 220-233.

Offenbacher S, Katz V, Fertik G, Collins J, Boyd D, Maynor G, McKaig R, Beck J. 1996. Periodontal infection as a possible risk factor for preterm low birth weight. J Periodontol 67: 1103-1113.

Offenbacher S, Beck JD, Jared HL, Mauriello SM, Mendoza LC, Couper DJ, Stewart DD, Murtha AP, Cochran DL, Dudley DJ, et al. 2009. Effects of periodontal therapy on rate of preterm delivery: A randomized controlled trial. Obstet Gynecol 114: 551-559.

Olomu IN, Hecht JL, Onderdonk AO, Allred EN, Leviton A. 2009. Perinatal correlates of Ureaplasma urealyticum in placenta parenchyma of singleton pregnancies that end before 28 weeks of gestation. Pediatrics 123: 1329-1336.

Onderdonk AB, Delaney ML, DuBois AM, Allred EN, Leviton A. 2008a. Detection of bacteria in placental tissues obtained from extremely low gestational age neonates. Am J Obstet Gynecol 198: 110.e1-110.e7.

Onderdonk AB, Hecht JL, McElrath TF, Delaney ML, Allred EN, Leviton A. 2008b. Colonization of second- 
A.L. Prince et al.

trimester placenta parenchyma. Am J Obstet Gynecol 199: 52.e1-52.e10.

Paavonen J. 1983. Physiology and ecology of the vagina. Scand J Infect Dis Suppl 40: 31-35.

Palmer C, Bik EM, DiGiulio DB, Relman DA, Brown PO. 2007. Development of the human infant intestinal microbiota. PLoS Biol 5: el77.

Penders J, Thijs C, Vink C, Stelma FF, Snijders B, Kummeling I, van den Brandt PA, Stobberingh EE. 2006. Factors influencing the composition of the intestinal microbiota in early infancy. Pediatrics 118: 511-521.

Perla ME, Ghee AE, Sánchez S, McClelland RS, Fitzpatrick AL, Suárez-Ognio L, Lama JR, Sánchez J. 2012. Genital tract infections, bacterial vaginosis, HIV, and reproductive health issues among Lima-based clandestine female sex workers. Infect Dis Obstet Gynecol 2012: 739624.

Pettker CM, Buhimschi IA, Magloire LK, Sfakianaki AK, Hamar BD, Buhimschi CS. 2007. Value of placental microbial evaluation in diagnosing intra-amniotic infection. Obstet Gynecol 109: 739-749.

Pop M. 2009. Genome assembly reborn: Recent computational challenges. Brief Bioinform 10: 354-366.

Prakash T, Taylor TD. 2012. Functional assignment of metagenomic data: Challenges and applications. Brief Bioinform 13: 711-727.

Pruesse E, Quast C, Knittel K, Fuchs BM, Ludwig W, Peplies J, Glöckner FO. 2007. SILVA: A comprehensive online resource for quality checked and aligned ribosomal RNA sequence data compatible with ARB. Nucleic Acids Res 35: 7188-7196.

Pybus V, Onderdonk AB. 1999. Microbial interactions in the vaginal ecosystem, with emphasis on the pathogenesis of bacterial vaginosis. Microbes Infect 1: 285-292.

Qin J, Li Y, Cai Z, Li S, Zhu J, Zhang F, Liang S, Zhang W, Guan Y, Shen D, et al. 2012. A metagenome-wide association study of gut microbiota in type 2 diabetes. Nature 490: 55-60.

Ravel J, Gajer P, Abdo Z, Schneider GM, Koenig SSK, Mcculle SL, Ault K, Peralta L, Forney LJ. 2010. Vaginal microbiome of reproductive-age women. Proc Natl Acad Sci 108: $4680-4687$.

Redline RW. 2007. Villitis of unknown etiology: Noninfectious chronic villitis in the placenta. Hum Pathol 38: 1439-1446.

Redondo-Lopez V, Cook RL, Sobel JD. 1990. Emerging role of lactobacilli in the control and maintenance of the vaginal bacterial microflora. Rev Infect Dis 12: 856-872.

Ridaura VK, Faith JJ, Rey FE, Cheng J, Duncan AE, Kau AL, Griffin NW, Lombard V, Henrissat B, Bain JR, et al. 2013. Gut microbiota from twins discordant for obesity modulate metabolism in mice. Science 341: 1241214.

Riehle K, Coarfa C, Jackson A, Ma J, Tandon A, Paithankar S, Raghuraman S, Mistretta T-A, Saulnier D, Raza S, et al. 2012. The Genboree Microbiome Toolset and the analysis of $16 \mathrm{~S}$ rRNA microbial sequences. BMC Bioinformatics 13: S11.

Rogier EW, Frantz AL, Bruno MEC, Wedlund L, Cohen DA, Stromberg AJ, Kaetzel CS. 2014. Secretory antibodies in breast milk promote long-term intestinal homeostasis by regulating the gut microbiota and host gene expression. Proc Natl Acad Sci 111: 3074-3079.
Romero R, Sirtori M, Oyarzun E, Avila C, Mazor M, Callahan R, Sabo V, Athanassiadis AP, Hobbins JC. 1989. Infection and labor. V: Prevalence, microbiology, and clinical significance of intraamniotic infection in women with preterm labor and intact membranes. Am J Obstet Gynecol 161: 817-824.

Romero R, Hassan SS, Gajer P, Tarca AL, Fadrosh DW, Bieda J, Chaemsaithong P, Miranda J, Chaiworapongsa T, Ravel J. 2014a. The vaginal microbiota of pregnant women who subsequently have spontaneous preterm labor and delivery and those with a normal delivery at term. Microbiome 2: 18.

Romero R, Hassan SS, Gajer P, Tarca AL, Fadrosh DW, Nikita L, Galuppi M, Lamont RF, Chaemsaithong P, Miranda J, et al. 2014b. The composition and stability of the vaginal microbiota of normal pregnant women is different from that of non-pregnant women. Microbiome 2: 4.

Ruiz-Pesini E, Lott MT, Procaccio V, Poole JC, Brandon MC, Mishmar D, Yi C, Kreuziger J, Baldi P, Wallace DC. 2007. An enhanced MITOMAP with a global mtDNA mutational phylogeny. Nucleic Acids Res 35: D823-D828.

Schloss PD, Westcott SL, Ryabin T, Hall JR, Hartmann M, Hollister EB, Lesniewski RA, Oakley BB, Parks DH, Robinson CJ, et al. 2009. Introducing mothur: Open-source, platform-independent, community-supported software for describing and comparing microbial communities. Appl Environ Microbiol 75: 7537-7541.

Schmieder R, Lim YW, Edwards R. 2012. Identification and removal of ribosomal RNA sequences from metatranscriptomes. Bioinformatics 28: 433-435.

Schultz M, Göttl C, Young RJ, Iwen P, Vanderhoof JA. 2004 Administration of oral probiotic bacteria to pregnant women causes temporary infantile colonization. J Pediatr Gastroenterol Nutr 38: 293-297.

Schwiertz A, Gruhl B, Löbnitz M, Michel P, Radke M, Blaut M. 2003. Development of the intestinal bacterial composition in hospitalized preterm infants in comparison with breast-fed, full-term infants. Pediatr Res 54: 393-399.

Schwiertz A, Taras D, Schäfer K, Beijer S, Bos NA, Donus C, Hardt PD. 2010. Microbiota and SCFA in lean and overweight healthy subjects. Obesity (Silver Spring) 18: 190 195.

Segata N, Waldron L, Ballarini A, Narasimhan V, Jousson O, Huttenhower C. 2012. Metagenomic microbial community profiling using unique clade-specific marker genes. Nat Methods 9: 811-814.

Sellitto M, Bai G, Serena G, Fricke WF, Sturgeon C, Gajer P, White JR, Koenig SSK, Sakamoto J, Boothe D, et al. 2012. Proof of concept of microbiome-metabolome analysis and delayed gluten exposure on celiac disease autoimmunity in genetically at-risk infants. PLoS ONE 7: e33387.

Shi Y, Tyson GW, Eppley JM, DeLong EF. 2011. Integrated metatranscriptomic and metagenomic analyses of stratified microbial assemblages in the open ocean. ISME J 5: 999-1013.

Sobhani I, Tap J, Roudot-Thoraval F, Roperch JP, Letulle S, Langella P, Corthier G, Van Nhieu JT, Furet JP. 2011. Microbial Dysbiosis in Colorectal Cancer (CRC) Patients. PLoS ONE 6: e16393.

Steel JH, Malatos S, Kennea N, Edwards AD, Miles L, Duggan P, Reynolds PR, Feldman RG, Sullivan MHF. 2005. 
Bacteria and inflammatory cells in fetal membranes do not always cause preterm labor. Pediatr Res 57: 404-411.

Stout MJ, Conlon B, Landeau M, Lee I, Bower C, Zhao Q, Roehl KA, Nelson DM, Macones GA, Mysorekar IU. 2013. Identification of intracellular bacteria in the basal plate of the human placenta in term and preterm gestations. Am J Obstet Gynecol 208: 226.e1-226.e7.

Swati P, Thomas B, Vahab SA, Kapaettu S, Kushtagi P. 2012. Simultaneous detection of periodontal pathogens in subgingival plaque and placenta of women with hypertension in pregnancy. Arch Gynecol Obstet 285: 613-619.

Turnbaugh PJ, Ley RE, Mahowald MA, Magrini V, Mardis ER, Gordon JI. 2006. An obesity-associated gut microbiome with increased capacity for energy harvest. Nature 444: $1027-1031$

Turnbaugh PJ, Bäckhed F, Fulton L, Gordon JI. 2008. Dietinduced obesity is linked to marked but reversible alterations in the mouse distal gut microbiome. Cell Host Microbe 3: 213-223.

Turnbaugh PJ, Hamady M, Yatsunenko T, Cantarel BL, Duncan A, Ley RE, Sogin ML, Jones WJ, Roe BA, Affourtit JP, et al. 2009. A core gut microbiome in obese and lean twins. Nature 457: 480-484.

Vermeulen GM, Bruinse HW. 1999. Prophylactic administration of clindamycin $2 \%$ vaginal cream to reduce the incidence of spontaneous preterm birth in women with an increased recurrence risk: A randomised placebo-controlled double-blind trial. Br J Obstet Gynaecol 106: 652657.

Verstraelen H, Verhelst R, Claeys G, De Backer E, Temmerman M, Vaneechoutte M. 2009. Longitudinal analysis of the vaginal microflora in pregnancy suggests that L. crispatus promotes the stability of the normal vaginal microflora and that L. gasseri and/or L. iners are more conducive to the occurrence of abnormal vaginal microflora. BMC Microbiol 9: 116

Walther-António MRS, Jeraldo P, Berg Miller ME, Yeoman CJ, Nelson KE, Wilson BA, White BA, Chia N, Creedon DJ. 2014. Pregnancy's stronghold on the vaginal microbiome. PLOS ONE 9: e98514.

Wang Q, Garrity GM, Tiedje JM, Cole JR. 2007. Naive Bayesian classifier for rapid assignment of rRNA sequences into the new bacterial taxonomy. Appl Environ Microbiol 73: 5261-5267.

Wang T, Cai G, Qiu Y, Fei N, Zhang M, Pang X, Jia W, Cai S, Zhao L. 2012. Structural segregation of gut microbiota between colorectal cancer patients and healthy volunteers. ISME J 6: 320-329.

Wang X, Buhimschi CS, Temoin S, Bhandari V, Han YW, Buhimschi IA. 2013. Comparative microbial analysis of paired amniotic fluid and cord blood from pregnancies complicated by preterm birth and early-onset neonatal sepsis. PLoS ONE 8: e56131.

Watts DH, Krohn MA, Hillier SL, Eschenbach DA. 1992. The association of occult amniotic fluid infection with gestational age and neonatal outcome among women in preterm labor. Obstet Gynecol 79: 351-357.

Wiesenfeld HC, Hillier SL, Krohn MA, Landers DV, Sweet RL. 2003. Bacterial vaginosis is a strong predictor of Neisseria gonorrhoeae and Chlamydia trachomatis infection. Clin Infect Dis 36: 663-668.

Willing B, Halfvarson J, Dicksved J, Rosenquist M, Järnerot G, Engstrand L, Tysk C, Jansson JK. 2009. Twin studies reveal specific imbalances in the mucosa-associated microbiota of patients with ileal Crohn's disease. Inflamm Bowel Dis 15: 653-660.

Wu X, Ma C, Han L, Nawaz M, Gao F, Zhang X, Yu P, Zhao C, Li L, Zhou A, et al. 2010. Molecular characterisation of the faecal microbiota in patients with type II diabetes. Curr Microbiol 61: 69-78.

Yee WH, Soraisham AS, Shah VS, Aziz K, Yoon W, Lee SK. 2012. Incidence and timing of presentation of necrotizing enterocolitis in preterm infants. Pediatrics 129: e298304.

Zeldovich VB, Bakardjiev AI. 2012. Host defense and tolerance: Unique challenges in the placenta. PLoS Pathog 8: e1002804.

Zhang W, Li F, Nie L. 2010. Integrating multiple "omics" analysis for microbial biology: Application and methodologies. Microbiology 156: 287-301.

Zhu W, Lomsadze A, Borodovsky M. 2010. Ab initio gene identification in metagenomic sequences. Nucleic Acids Res 38: e132. 


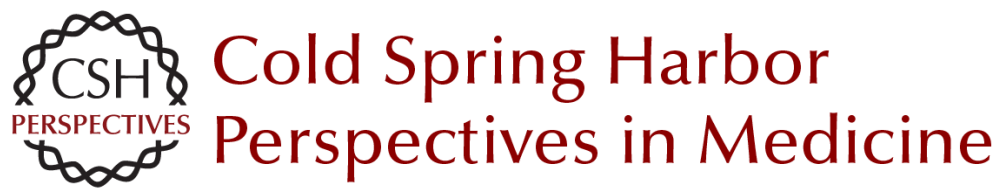

\title{
The Perinatal Microbiome and Pregnancy: Moving Beyond the Vaginal Microbiome
}

\author{
Amanda L. Prince, Derrick M. Chu, Maxim D. Seferovic, Kathleen M. Antony, Jun Ma and Kjersti M. \\ Aagaard
}

Cold Spring Harb Perspect Med 2015; doi: 10.1101/cshperspect.a023051 originally published online March 16, 2015

\section{Subject Collection Molecular Approaches to Reproductive and Newborn Medicine}

\author{
Intergenerational Transfer of Epigenetic \\ Information in Sperm \\ Oliver J. Rando
}

\section{Effects of Maternal Obesity on Fetal \\ Programming: Molecular Approaches Caterina Neri and Andrea G. Edlow}

The Neonatal Salivary Transcriptome Jill L. Maron

The Role of Hox Genes in Female Reproductive Tract Development, Adult Function, and Fertility Hongling Du and Hugh S. Taylor

\section{Molecular Cross-Talk at the Feto-Maternal Interface}

Gendie E. Lash

Molecular Regulation of Parturition: A Myometrial Perspective Nora E. Renthal, Koriand'r C. Williams, Alina P. Montalbano, et al.

Genome-Wide Sequencing for Prenatal Detection of Fetal Single-Gene Disorders Ignatia B. Van den Veyver and Christine M. Eng

MicroRNA in Ovarian Biology and Disease Lynda K. McGinnis, Lacey J. Luense and Lane K. Christenson
A Molecular Perspective on Procedures and Outcomes with Assisted Reproductive Technologies Monica A. Mainigi, Carmen Sapienza, Samantha Butts, et al.

Whole-Exome Sequencing and Whole-Genome Sequencing in Critically III Neonates Suspected to Have Single-Gene Disorders Laurie D. Smith, Laurel K. Willig and Stephen F. Kingsmore

Noninvasive Antenatal Determination of Fetal

Blood Group Using Next-Generation Sequencing Klaus Rieneck, Frederik Banch Clausen and Morten Hanefeld Dziegiel

Potential Uses and Inherent Challenges of Using Genome-Scale Sequencing to Augment Current Newborn Screening Jonathan S. Berg and Cynthia M. Powell

Molecular Regulation of Parturition: The Role of the Decidual Clock Errol R. Norwitz, Elizabeth A. Bonney, Victoria V. Snegovskikh, et al.

Molecular Mechanisms of Preeclampsia Tammy Hod, Ana Sofia Cerdeira and S. Ananth Karumanchi

Noninvasive Prenatal Screening for Genetic Diseases Using Massively Parallel Sequencing of Maternal Plasma DNA Lyn S. Chitty and Y. M. Dennis Lo

Confrontation, Consolidation, and Recognition: The Oocyte's Perspective on the Incoming Sperm David Miller

For additional articles in this collection, see http://perspectivesinmedicine.cshlp.org/cgi/collection/ 